\title{
The high-density thickened discharge tailings storage facility at Osborne Mine - a case history from inception to closure
}

\author{
GI McPhail SLR Consulting Australia Pty Ltd, Australia
}

\begin{abstract}
Chinova Resources Pty Ltd's Osborne Mine is located in Northern Queensland, approximately $800 \mathrm{~km}$ inland from the eastern coast. It commenced operations in 1995 with the development of an open pit mine. In 1996, the operation transitioned to underground mining. In 2015, Osborne will have been in operation for 20 years and will have mined $29 \mathrm{Mt}$ of ore. The site has produced 672, $420 \mathrm{t}$ of copper and 673,295 oz of gold.

Osborne Mine produces approximately 112,000 t of tailings per month. In 2003, following progressive evaluation and development of a high-density discharge tailings management system, Osborne implemented the first of two trial depositions forming advancing cones of deposited tailings within their TSF2 site. These trials proved successful and, following successful permit applications to the regulators, TSF2 was converted to high-density thickened tailings discharge. The principal benefit of this change was in the reduction of construction costs for confining embankments. However, an additional major benefit lay in a reduction of make-up water volumes. The majority of water loss in the process water circuit occurs in the tailings system as a result of evaporation. High-density thickened discharge provides a means for significantly reducing water losses, since, by recovering and re-using more water at the thickener and in the plant, less water is discharged onto the tailings facility so there is less water available for evaporation. High-density thickened discharge also enabled a significant improvement in operating costs.

High-density thickened discharge operations at Osborne have had to be continuously modified and adjusted as ores from satellite mines have been processed to supplement the diminishing Osborne Mine ore. Mineralogical influences of the supplementary ore significantly affect the thickening and beaching characteristics of the tailings slurry, particularly in the most recent operating period. However, through appropriate modifications and adjustments, the benefits of high-density thickened discharge have been retained.

The resulting tailings storage facility (TSF) landform is that of a shallow-sloped shedding mound so that there is no need to retain water on the TSF. Chinova has been proactive with ongoing site monitoring and rehabilitation with a view to shedding runoff to the environment. Their site plans include ensuring that the discharge water from the site will meet the stock-water guidelines, and that the erosion gullies forming in TSF cover materials or on the side slopes of confining embankments will not result in exposure of the tailings over 500 years.
\end{abstract}

\section{Introduction}

Osborne Mine in Northern Queensland, Australia is located in outback Australia approximately $800 \mathrm{~km}$ southwest of Cairns as indicated in Figure 1. It is an underground copper-gold operation that mines an ironstone deposit which hosts magnetite and silica with chalcopyrite, pyrite, and pyrrhotite. The mine setting is arid with an average annual rainfall of $335 \mathrm{~mm}$ and an annual average evaporation rate of $3,150 \mathrm{~mm}$. Rainfall generally occurs between October and March and is largely dependent on cyclone activity over the north of the Australian continent. The majority of make-up water for the mine is supplied from boreholes located on the edge of the Great Artesian Basin, some $28 \mathrm{~km}$ from the mine site. While there are vast quantities of water stored in the basin, regulators are conscientious in encouraging users to 
maximise water use efficiency. In addition, Osborne's sustainability commitments serve as major drivers in the development of strategies to reduce water use from the Great Artesian Basin.

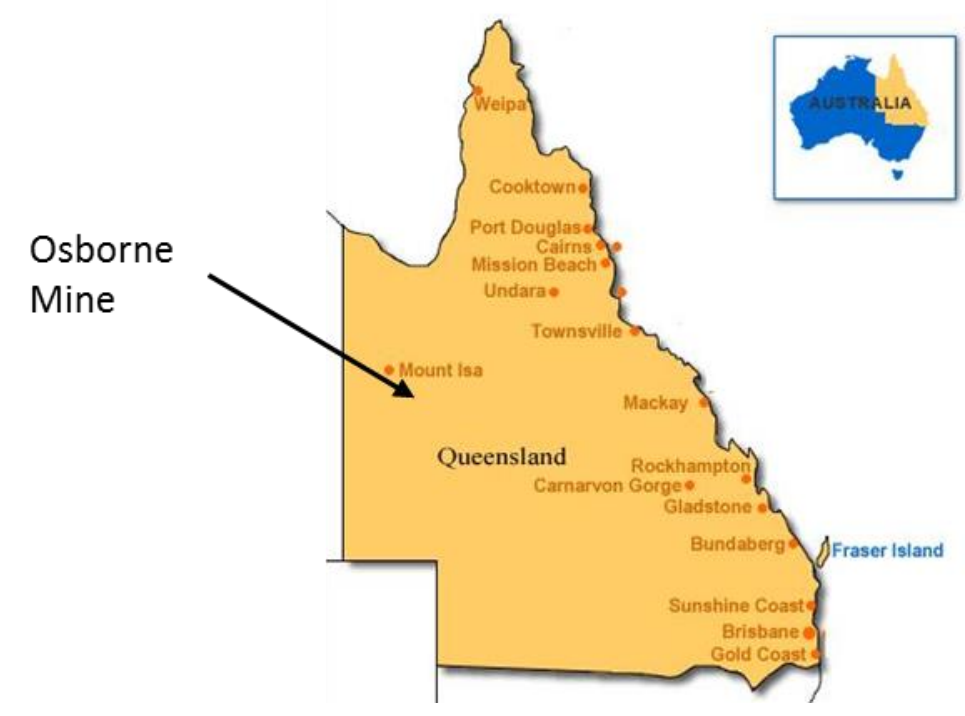

\section{Figure 1 Locality map}

It was in view of the water sustainability issues that Osborne decided to consider high-density thickened tailings (HDTT) production. The majority of water loss on a TSF is through evaporation and seepage and it followed that if the volume of water discharged onto the TSF was reduced then evaporation and seepage would reduce. Assessment of the feasibility of HDTT began in 2000 with a view to implementing this on a new TSF (TSF2), which was in the process of being sited. The assessment included rheological, pumping and piping assessments, as well as beaching assessments, that then led to progressive increases in slurry density and trials on the existing TSF (TSF1). However, management saw this foray into HDTT as high risk and insisted on a formal risk assessment workshop with the regulator as a workshop participant to assist in assessing the risk that HDTT may be rejected should applications to adopt HDTT be submitted for regulatory approval. The regulator was not averse to the approach, but set a requirement that a thorough geotechnical assessment with specific evaluation on liquefaction risks would need to form part of any submission. Management decided against HDTT and the design of TSF2 proceeded on the basis of a TSF design for conventional tailings. TSF2 was subsequently constructed and commissioned as a conventional TSF whereby initial starter embankments were constructed and progressively raised on an upstream basis.

The starter embankments were sized on the basis that they should provide two years of containment before the first raise with the tonnage to be stored set at $60 \%$ of production, as it was planned that $40 \%$ of the tailings would be diverted directly to underground mine backfill. By the time of commissioning TSF2, the advantages of raising the slurry percent solids from 50 to $65 \%$, in terms of smaller pumping volume and lower water usage, were already entrenched in operations. However, a combination of a steeper beach slope, as a result of the higher percent solids, and the fact that no underground backfill was diverted from the TSF resulted in the tailings reaching the top elevation of the starter embankments after only nine months as opposed to the planned two years.

To avoid the need for further capital expenditure, a decision was made by mine management to buy time by using HDTT. Thickening processes were further refined and a full-scale trial commenced on TSF2. The trial enabled field testing of the deposited tailings and comparison with the laboratory testing to assess geotechnical and liquefaction characteristics. Based on the full-scale trial experience, and armed with appropriate geotechnical data, Osborne made application to convert the facility from a conventional to HDTT operation and this application was subsequently approved by the regulators.

Since this initial approval, the footprint of TSF2 has been extended to accommodate additional ore to be brought in from satellite mines. However, the ore from the satellite mines proved to be of different 
mineralogy to the Osborne ore and this resulted in reduced thickener efficiency and lower slurry density, with a concomitant flattening of beach slope. Blending of the ore, changes in flocculant types and dosages and a number of mechanical modifications went someway to improving slurry density, but it was necessary to amend the discharge method as well as to design for a flatter slope, which subsequently led to further increases in the footprint of the TSF.

TSF2 is due to be decommissioned in the third quarter of 2015. Closure planning has been effected and is in the final stages of approval by the regulator. The facility is a shedding landform and appropriate covers and erosion control measures have been designed and trialled in arriving at an appropriate cover design. In all, some $7 \mathrm{Mt}$ of tailings will have been stored in the facility.

This paper describes the Osborne tailings, summarises rheological, pumping and beaching assessments as well as geotechnical investigations, and documents the progressive development of the facility from inception in 2001 to eminent closure in 2015. It sets out the cover design and trials that have formed the basis of the final landform closure design.

\section{The Osborne tailings materials}

\section{$2.1 \quad$ Mineralogy}

Although the tailings comprise mostly magnetite, it also contains a number of sulfide minerals, notably pyrite with traces of chalcopyrite, together with gypsum. Sulphides make up 2 to $4 \%$ of the tailings mass. The sulphides are moderately reactive and to counter their acid generating capacity lime is added in the course of mineral processing. Gypsum is produced as a result of the neutralisation reactions.

The high iron content of the tailings causes the particle specific gravity to be 3.4 to 3.6.

\subsection{Particle-size distribution}

Figure 2 shows typical particle-size distributions for the tailings measured using a sieve and hydrometer.

From Figure 2 it is evident that:

- $60 \%$ of the tailings is finer than $75 \mu \mathrm{m}$.

- The maximum particle size is $2 \mathrm{~mm}$.

- Approximately $25 \%$ of the tailings have a particle size in a narrow range from 0.06 to $0.08 \mathrm{~mm}$. 


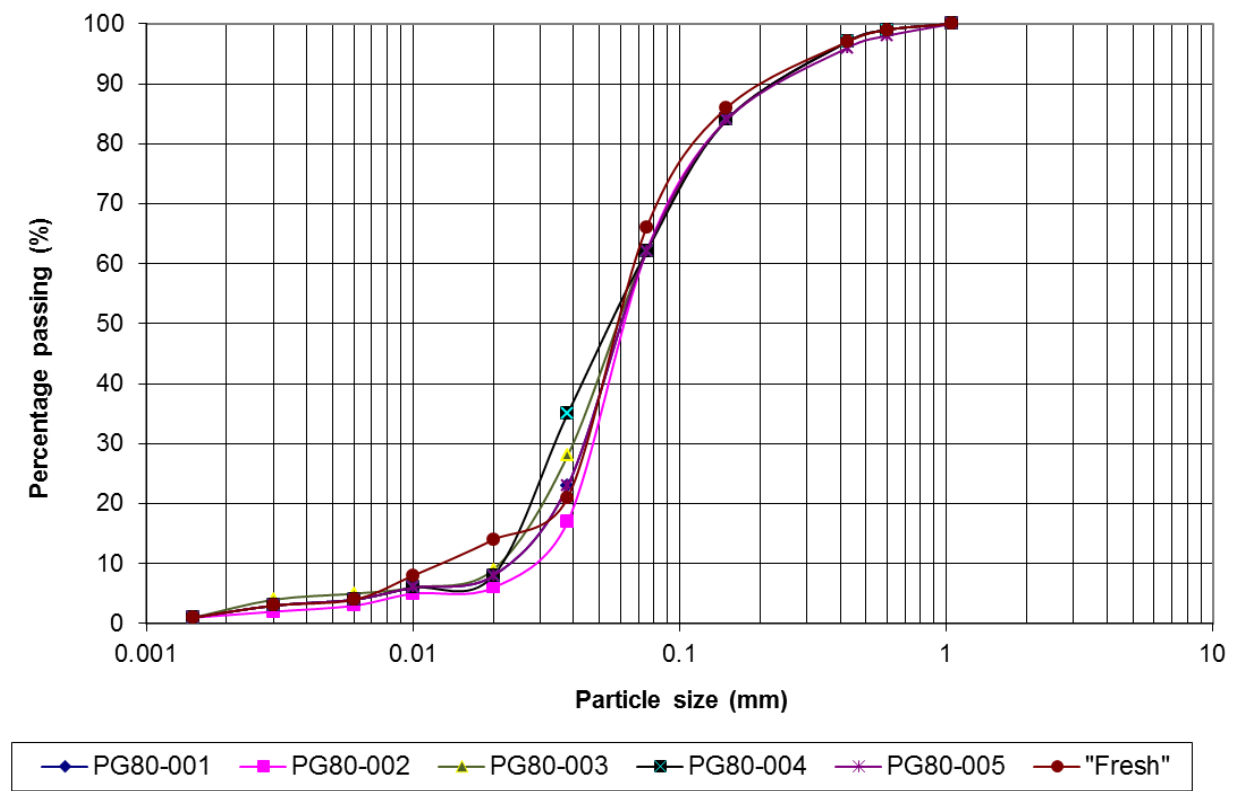

\section{Figure 2 Typical particle-size distributions of the tailings}

\subsection{Tailings geochemistry}

Geochemical testing and assessment of the tailings material confirmed that the tailings produce acidity and sulphate upon oxidation. The reaction rate is, however, relatively slow. The average sulphide-based sulfur concentration is $2.4 \%$ for TSF2. The presence of gypsum in significant quantities in the tailings indicates that acid-base reactions occur early in the tailings deposition history, probably as soon as lime is added to the slurry immediately prior to deposition of the tailings. Acid generation continues within the deposited tailings mass. The acid-base accounting test-work indicates there is insufficient neutralisation capacity within the tailings to buffer all potential acidity.

TSF2 has an acid producing potential of $42.5 \mathrm{~kg} / \mathrm{t}$ of tailings. Calcium minerals and magnesium minerals are consumed in the acid-base reaction and their derivatives report to leachate.

Water emanating from TSF2 will have issues in respect of:

- $\mathrm{pH}$, conductivity and sulfate.

- $\mathrm{Cu}, \mathrm{Zn}, \mathrm{Co}, \mathrm{Ni}$ and Se.

TSF2 was sited to take advantage of the low permeability of the intact Mesozoic silcrete rock underlying the site and underdrains and seepage cutoff trenches up to $5 \mathrm{~m}$ deep were incorporated into the design of the embankments to both the TSF and the associated reclaim pond.

\section{Assessment of the feasibility of producing and managing HDTT}

Assessment of the feasibility of the production and management of HDTT began in 2000 with slurry rheological, pumping and beaching assessments in tandem with the assessment of potential modifications to the thickening circuit. These are set out below.

\subsection{Slurry rheology}

\subsubsection{Laboratory testing}

Laboratory viscometer testing was undertaken on the Osborne tailings at a range of solids contents. It was found that even at high percent solids the tailings settled in the viscometer so that the viscometer results were unreliable. Figure 3 shows the flow curves obtained. 

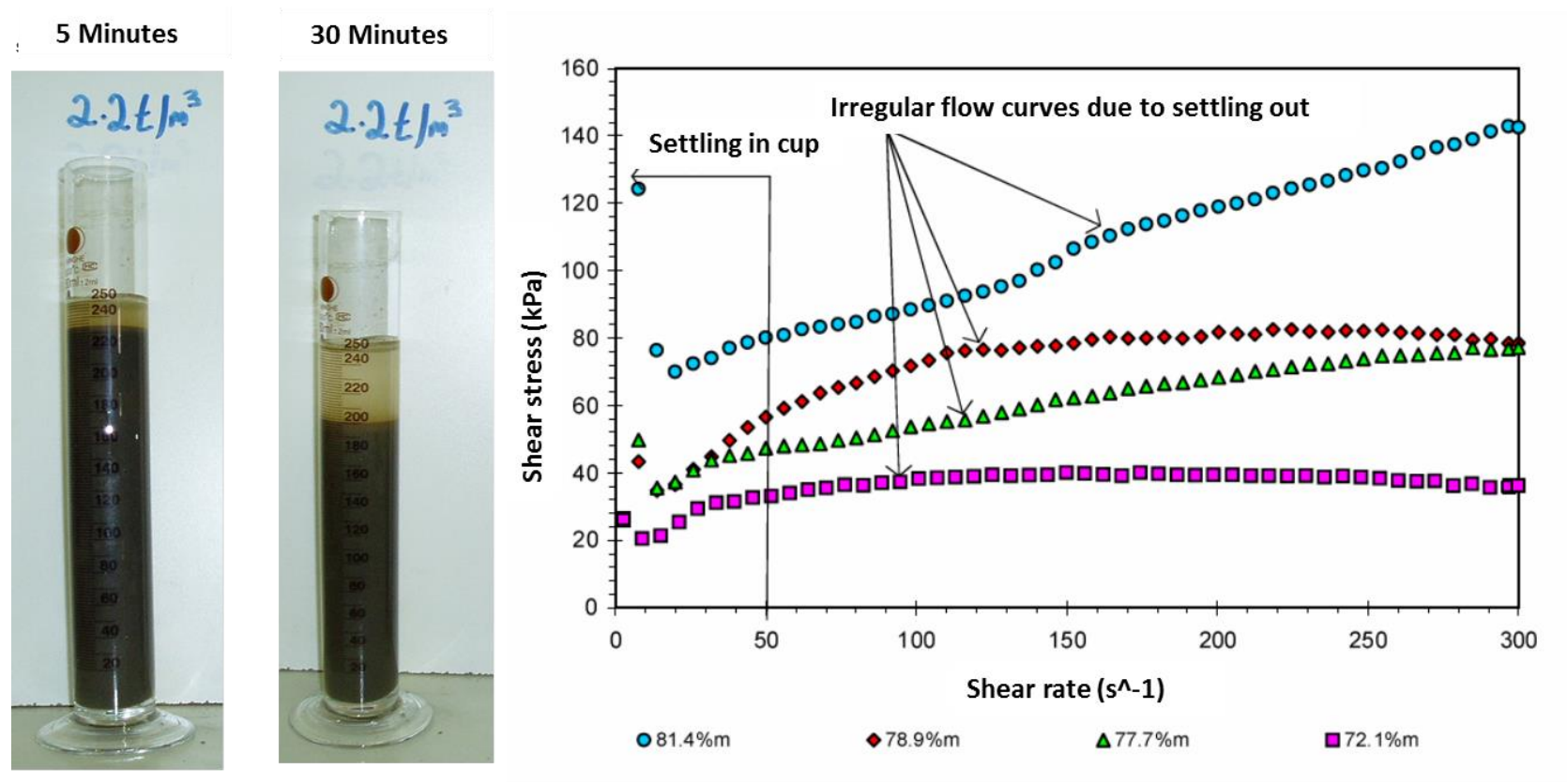

Figure 3 Laboratory rheological testing results on Osborne tailings

Slurries settling on a beach do so at shear rates that are generally less than $30 \mathrm{~s}^{-1}$ and, since the flow curves were particularly unreliable in the low shear rate zone, it was necessary to abandon the use of the laboratory rheological measurements. As the problem relates to settling out of the solids, it was decided to set up a rheological measurement test that would work with the settling out. To this end, small-scale flumes were selected as described in the next section.

\subsubsection{Flume testing}

The Osborne tailings were deposited at a rate of $0.8 \mathrm{~L} / \mathrm{s}$ into a flume measuring $7 \mathrm{~m}$ long by $0.5 \mathrm{~m}$ wide (McPhail 2008). Figure 4 shows the resultant beaches of slurry deposited into the flumes at a range of solids concentrations ( 68 to $74 \%$ SBW), along with corresponding post-calibration profiles using the McPhail model (McPhail 1995, 2008, 2014; Charlebois et al. 2013).

The flume results have been re-analysed using the latest analytical methods to determine shear rates and shear stresses at points down the beach formed in the flume (Charlebois et al. 2013). Particular emphasis was placed on estimating the yield stress. The results of the analyses are presented in Figure 5. 

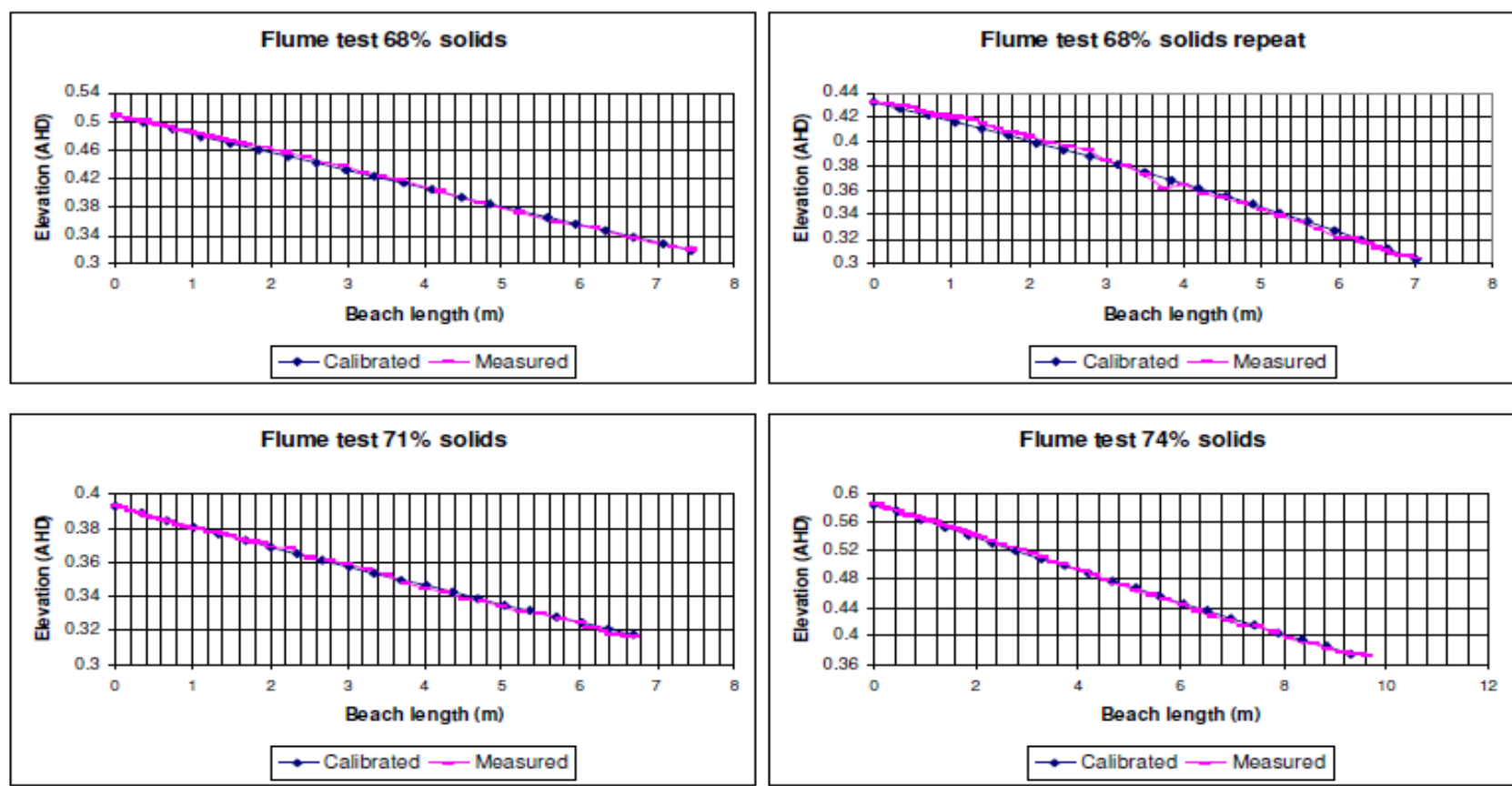

Figure 4 Results of flume testing and calibration of the McPhail stream power-entropy model for the Osborne thickened tailings at a range of solids concentrations (68 to $74 \%$ ) 


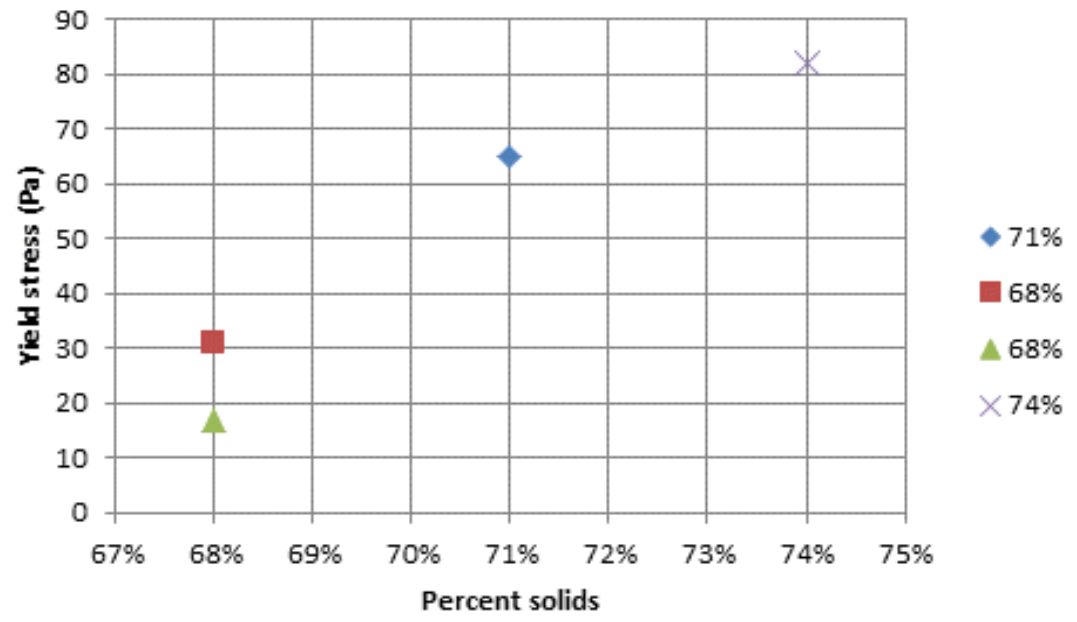

Figure 5 Yield stresses from the small scale flume tests

\subsubsection{Back analysis of full-scale beach profiles on TSF1}

The flume tests provided a theoretical basis for proceeding with full-scale trials. These were conducted as improvements to the thickening technology were developed (McPhail et al. 2004) over a period of almost two years, with the first step-up in percent solids from 55 to $65 \%$. The deposition at $65 \%$ solids, and subsequently at $68 \%$ solids, took place as part of routine operations on TSF1 while the initial earthworks for TSF2 were being constructed.

Beach modelling on the trial beach profiles was used to compliment the flume tests and provide improved data on which to ultimately justify carrying out further process plant modifications to raise the percent solids beyond $68 \%$.

The McPhail model was used to analyse the original $55 \%$ solids beach, as well as the two full-scale operating beaches formed at 65 and 68\% solids on TSF1. Figure 6 shows the measured and calibrated profiles.

Evaluation of the beaching analyses has been repeated with current methods of analysis which now permit the backward construct of representative flow diagrams for the tailings. More importantly, the understanding of the role of rheology in controlling the beaching behaviour has been refined and incorporated into the analyses. The yield stresses have been back-calculated from the full-scale beach profiles and added to the table of yield stresses from the flume testing. Figure 7 shows the resulting plot. It is evident from Figure 7 that the results from both flume tests undertaken for $68 \%$ solids are outliers from the trend of the other results. These have therefore been excluded and the best fit line from the results other than those for the $68 \%$ flume is indicated on Figure 7. 
TSF1 Full scale $\mathbf{5 5} \%$ solids

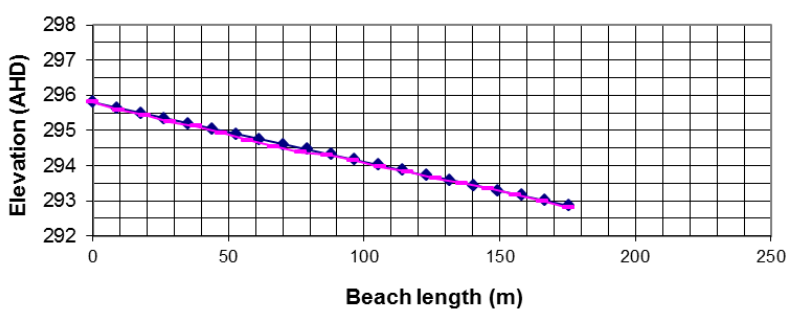

TSF1 Full scale $65 \%$ solids

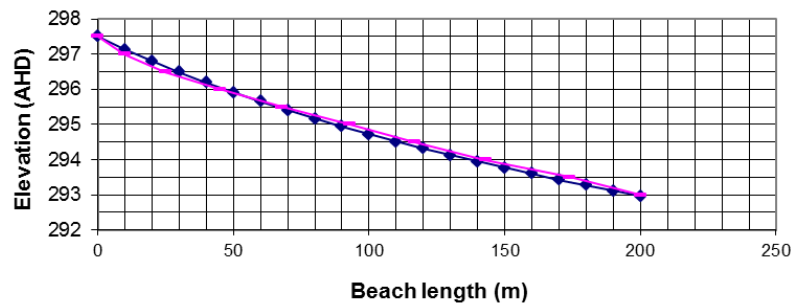

$\rightarrow$ Calibrated —-Measured

TSF1 Full scale $68 \%$ solids

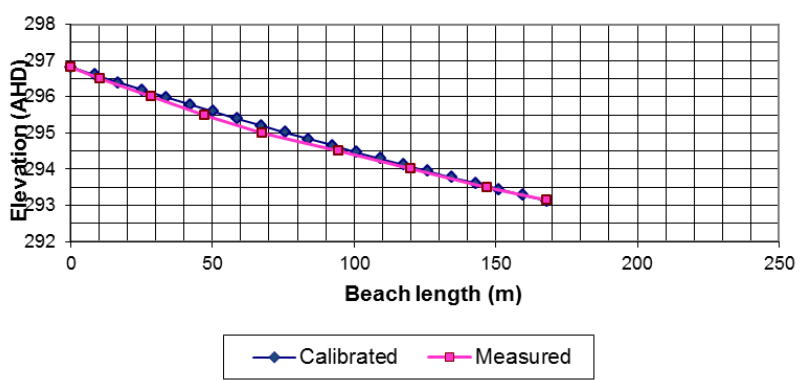

Figure 6 Beach profile predictions (using the calibrated model) and measure full-scale beaches formed by conventional Osborne tailings (55\%), and by thickened Osborne tailings $(66.5,68$, and $74 \%)$

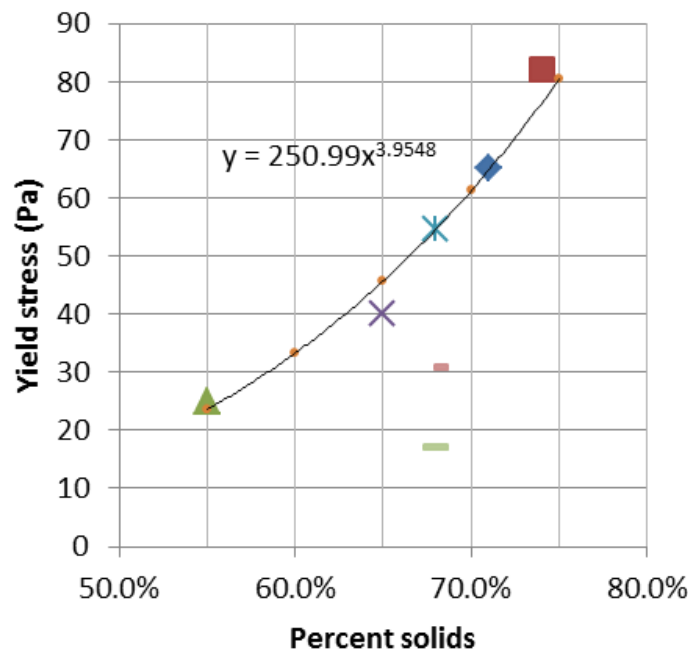

- $68 \%$ Flume

$\checkmark 71 \%$ flume

$74 \%$ flume

A Full scale $55 \%$ on TSF1

Full scale $65 \%$ on TSF1

* Full scale $68 \%$ on TSF1

- $68 \%$ Flume repeat

Power (Best fit line excl $68 \%$ flume points)

Figure 7 Yield stresses from the flume and full-scale trials on TSF1 


\subsection{Slurry pumping characteristics}

Slurry testing was conducted by Paterson and Cooke in the pipe loop located at Alrode in Johannesburg. Tests were conducted a range of water contents from 50 to $74 \%$ solids (slurry relative densities of 1.56 to 2.12 , respectively) to determine settling rates, friction characteristics and pump de-rating factors. Figure 8 shows some of the results of the testing.

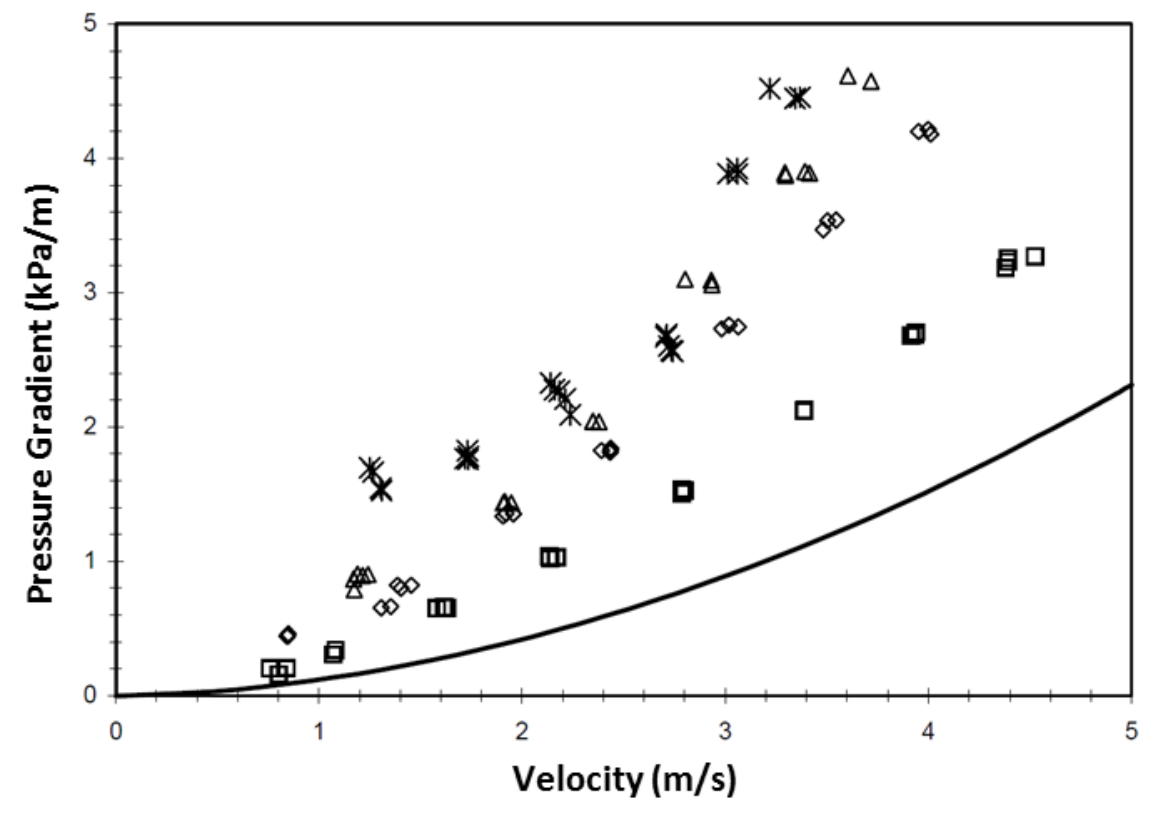

ㅁ $1.82 \mathrm{t} / \mathrm{m}^{3} \diamond 2.04 \mathrm{t} / \mathrm{m}^{3} \Delta 2.13 \mathrm{t} / \mathrm{m}^{3} * 2.20 \mathrm{t} / \mathrm{m}^{3}$-Water

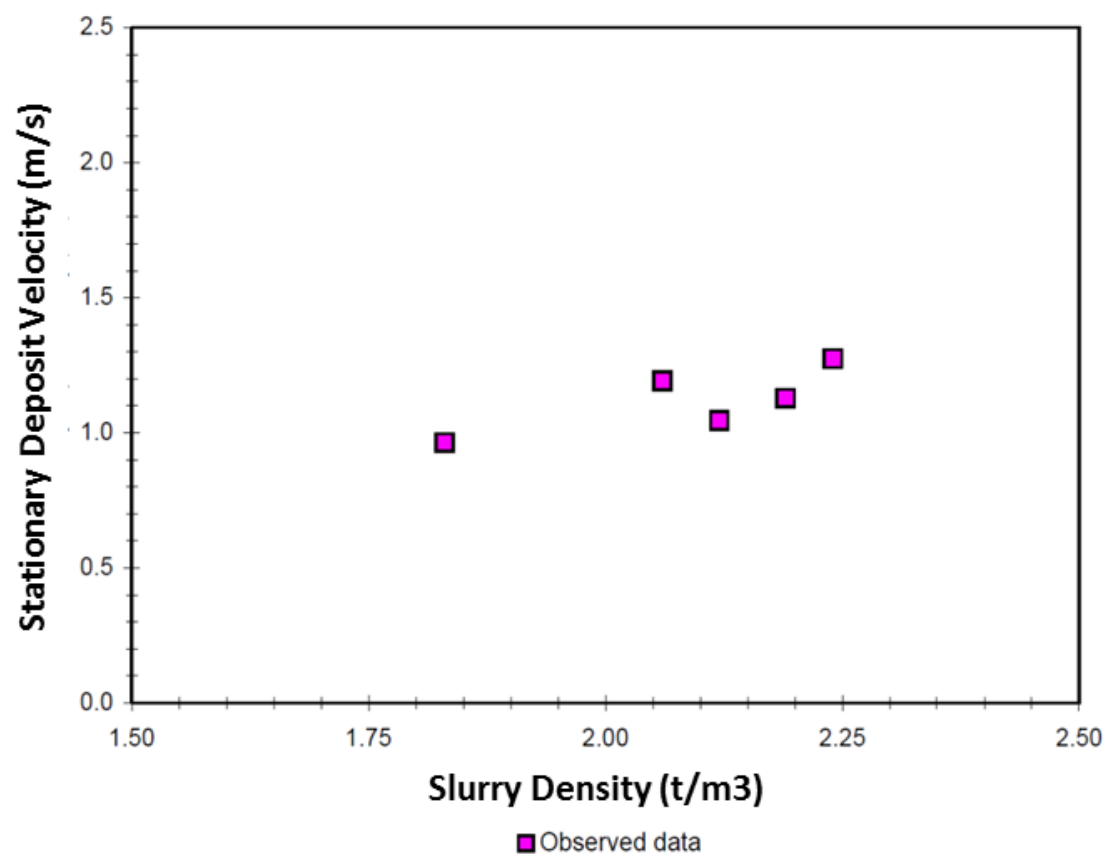

Figure 8 Pressure loss and settling velocities 


\section{$4 \quad$ Thickened tailings deposition trial}

\subsection{Set-up of the trial}

Figure 9 shows a series of isometric views of the thickened trial on the new tailings facility. The isometrics are produced from detailed topographic surveys of the original ground and the deposited tailings surface.

Use was made of a natural ridge within the new tailings facility to form a launch point from which to advance a single discharge pipe. As tailings beached and filled to the pipe-end, additional lengths of pipe were added and the discharge point progressively advanced forwards. In this way an advancing cone was formed. In addition, with each advance, the pipe discharge elevation was raised so that as the cone advanced the advancing face was at a rising elevation. This, together with the natural fall in the topography, enabled the formation of a cone face of approximately $10 \mathrm{~m}$ in vertical height from the end of the beached tailings to the discharge head. To control the deposition direction, a 60 degree ' $Y$ ' section was introduced in one pipe length before the discharge point and discharge alternated between the two branches.
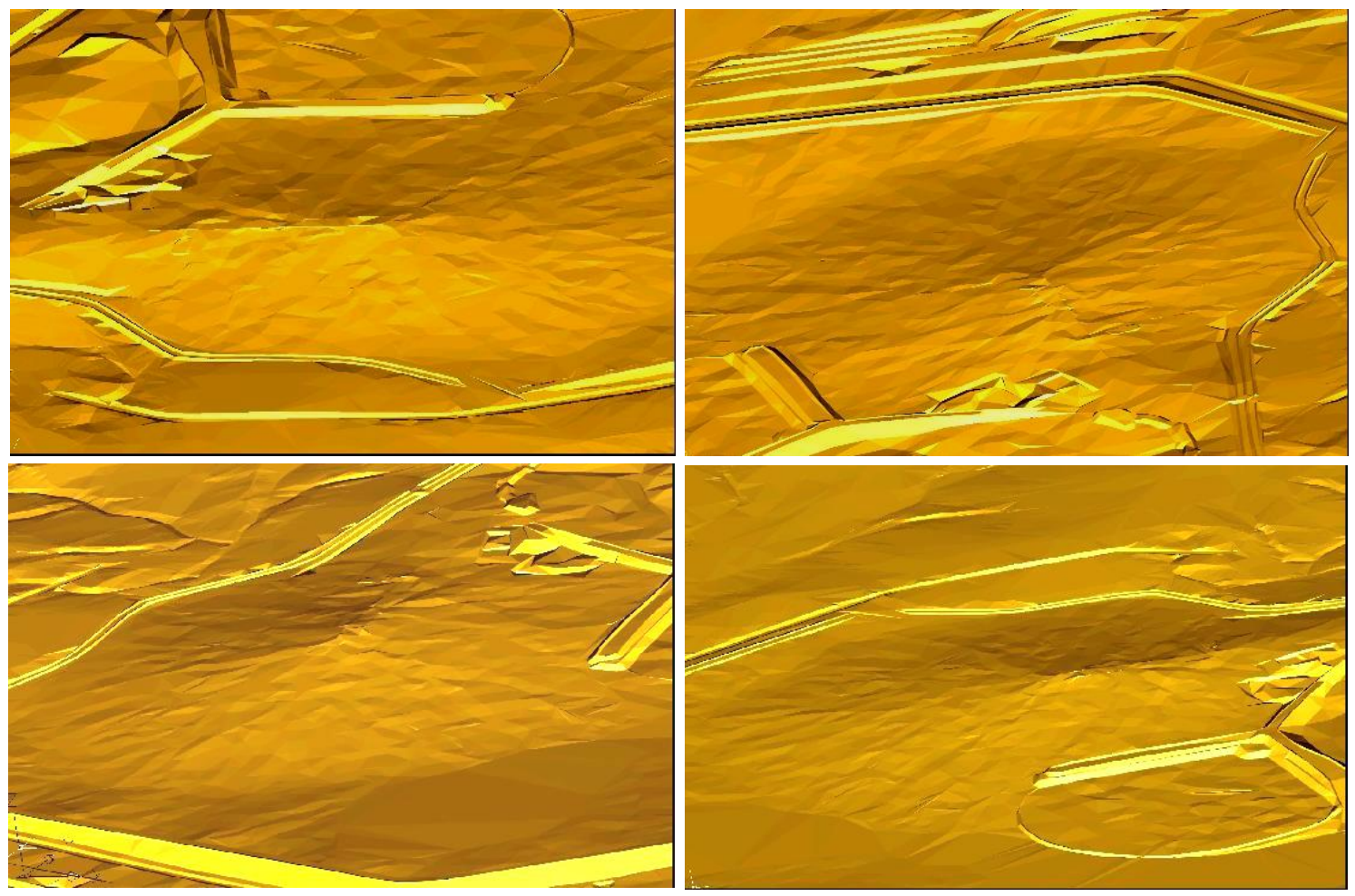

\section{Figure 9 Isometric views of the thickened trial on the new tailings facility}

The slopes of the mound were 1 in 20 for the upper half of the beach length and 1 in 30 for the lower half, giving an average beach slope of 1 in 25.

Figures 10 and 11 show two cross-sections through the thickened mound. The locations of piezocone soundings are also indicated on the sections. 


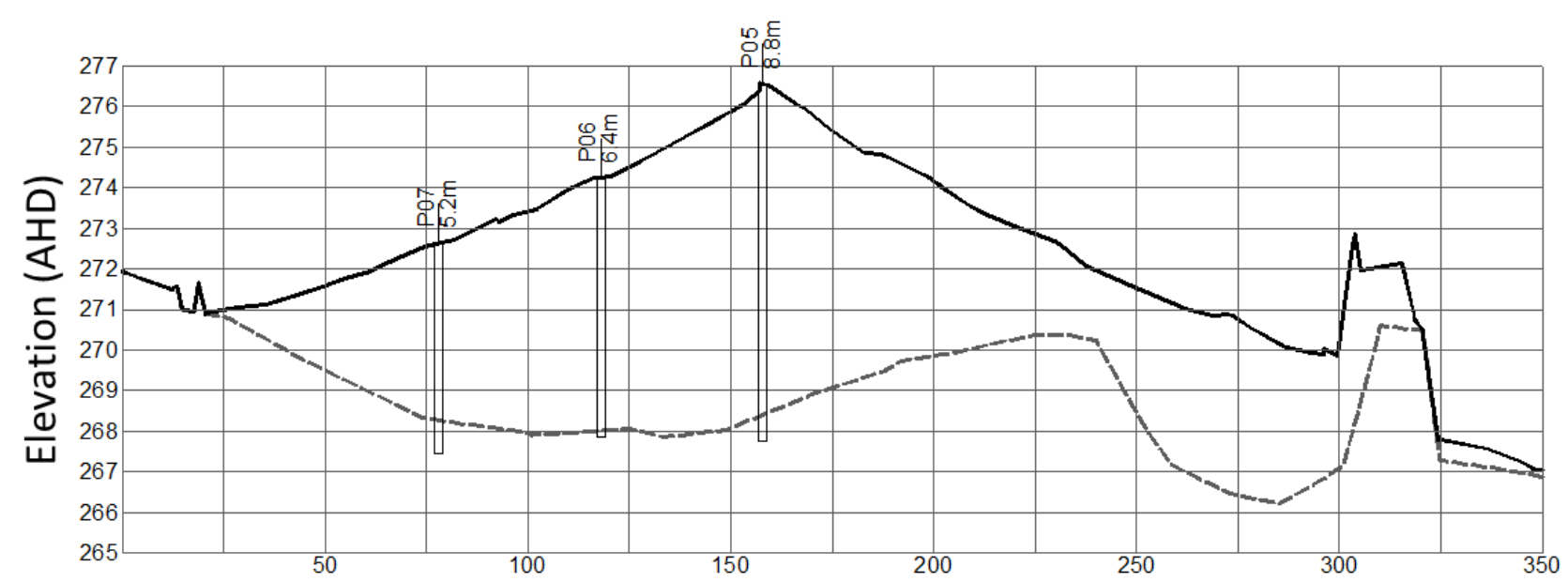

Figure 10 Section through the thickened mound from the outer confining embankment on the left to the pool wall on the right (vertical scale exaggerated)

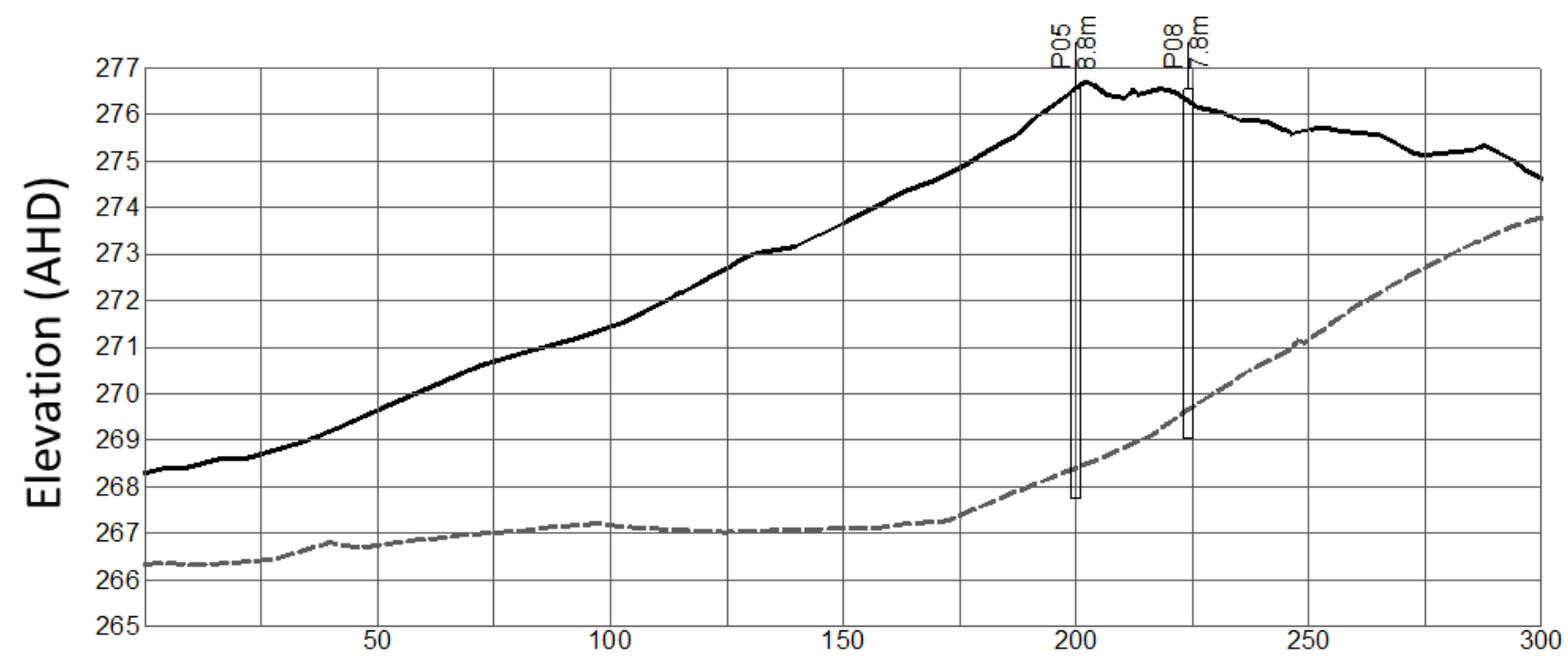

Figure 11 Section through the thickened mound along the delivery line route (vertical scale exaggerated)

Approximately $270,000 \mathrm{t}$ of tailings had been placed in the mound at the time of the survey. At an average measured in situ dry density of $2 \mathrm{t} / \mathrm{m}^{3}$, this represents approximately $135,000 \mathrm{~m}^{3}$ of tailings fill.

\subsection{Density control}

To achieve this special care was taken to ensure that only HDTT was discharged on the trial mound. A bypass arrangement that was triggered as soon as the density dropped below a slurry relative density of 2 (70\% solids) was incorporated into the flow control system. Flushing was kept to the minimum required to ensure that the delivery line would clear itself on the recommencement of slurry pumping.

On average, over the duration of the trial, the slurry density has been maintained at an average of 2.06 ( $72 \%$ solids), with regular excursions to $76 \%$ solids.

\subsection{Piezometric measurements}

The mound was instrumented using both standpipe piezometers as well as pore pressure transducers. The piezometers comprise PVC pipe slotted over the bottom $1 \mathrm{~m}$ and covered with a geofabric sock. Figure 12 shows the locations of the piezometers and Figure 13 shows typical standpipe piezometer readings. 


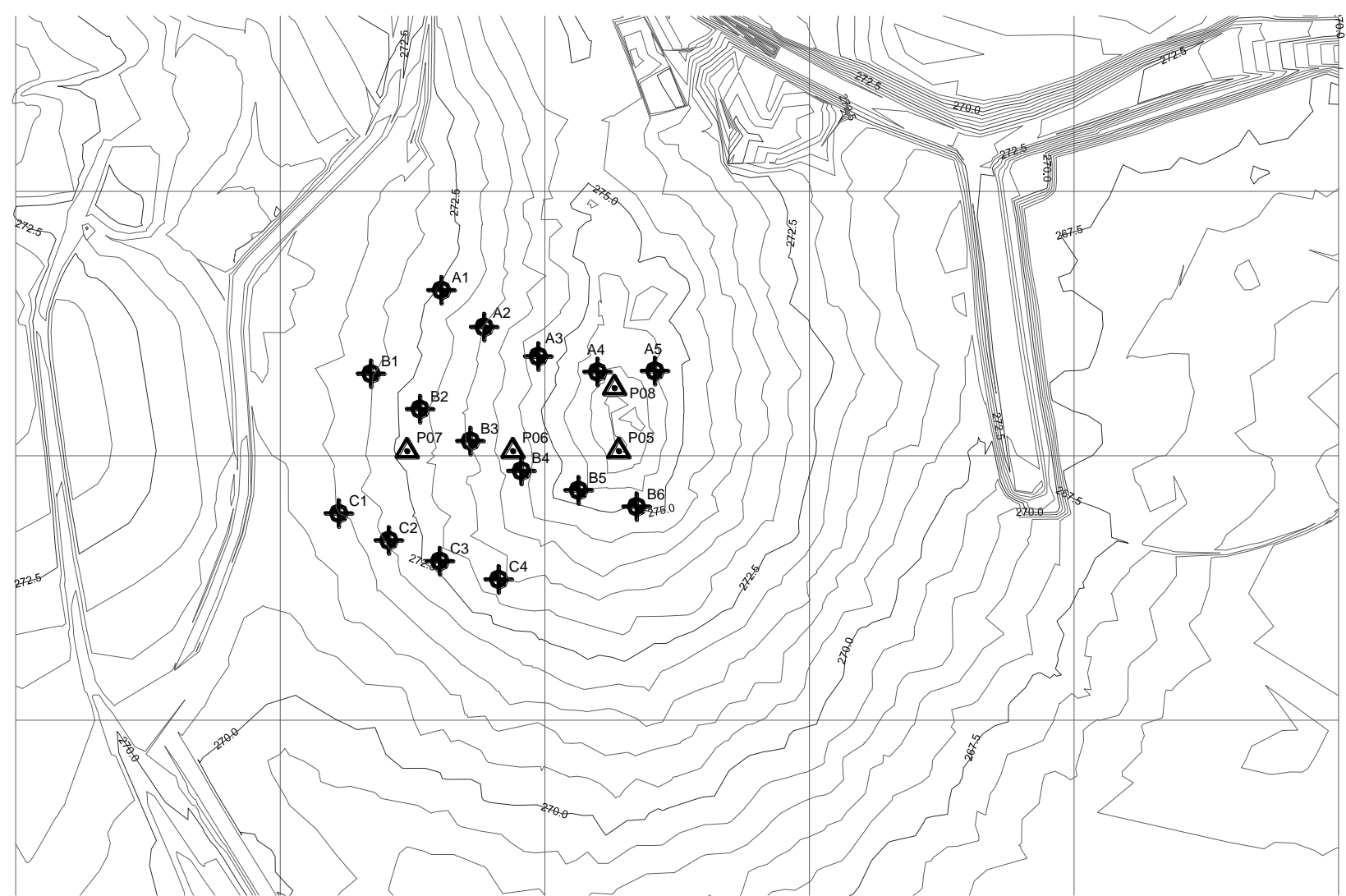

Figure 12 Plan of the thickened mound showing locations of piezometers (crosses) and piezometer cone soundings (triangles)
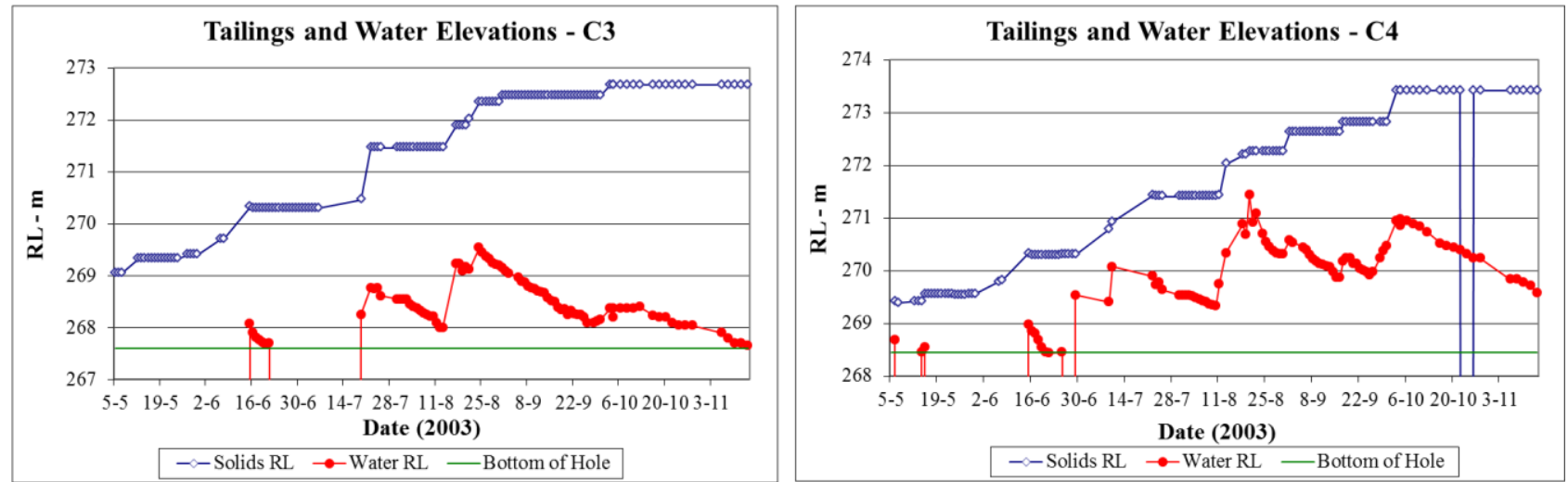

Figure 13 Typical standpipe piezometer measurements tracked against changes in tailings elevation at the standpipe

The rise and dissipation of the water levels is clearly evident from the piezometers. During deposition, particular attention was paid to the extent to which piezometer levels recovered between deposition episodes, as well as to the rising trend in the dissipated water level. It is also evident that the tailings coped well with the rates of rise in excess of $20 \mathrm{~m}$ per year.

Figure 14 shows a sequence of survey renders and indicates development of the southern and northern trial mounds. 


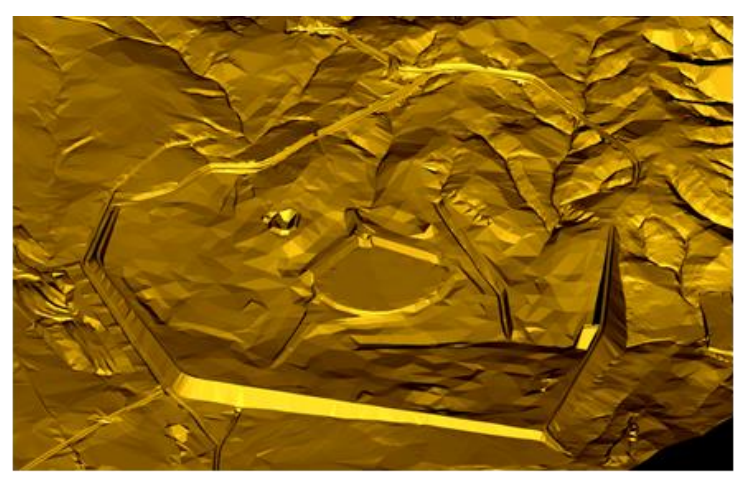

2002 soon after commissioning

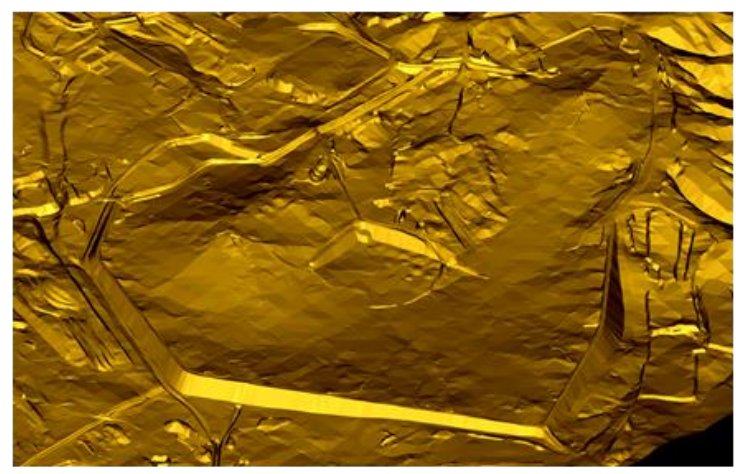

2004 Northern Trial, turn in Southern Trial

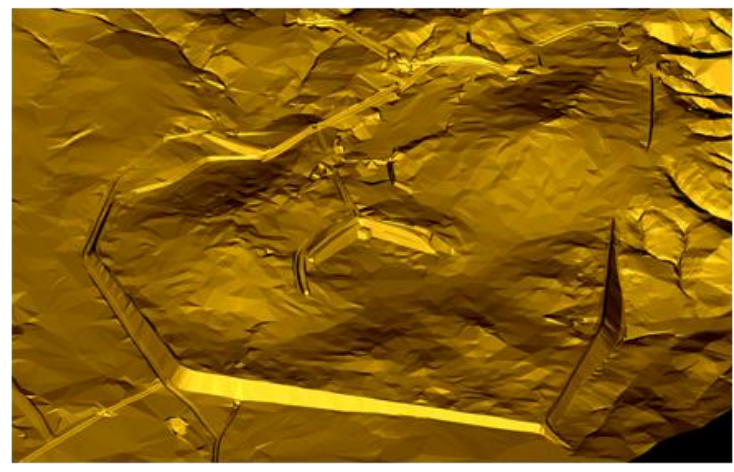

Oct 2005 beach filling to push pond onto drain pad

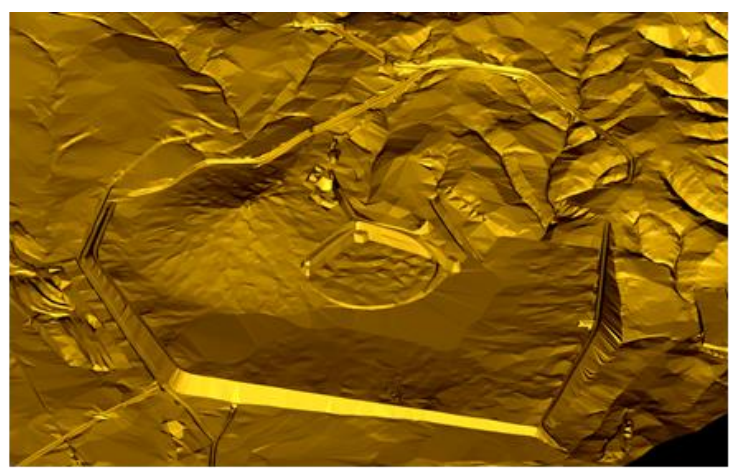

2003 Southern Trial

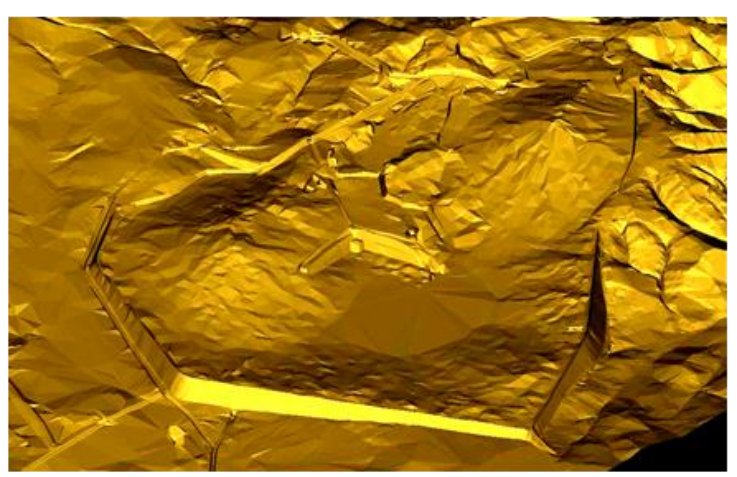

Feb 2005

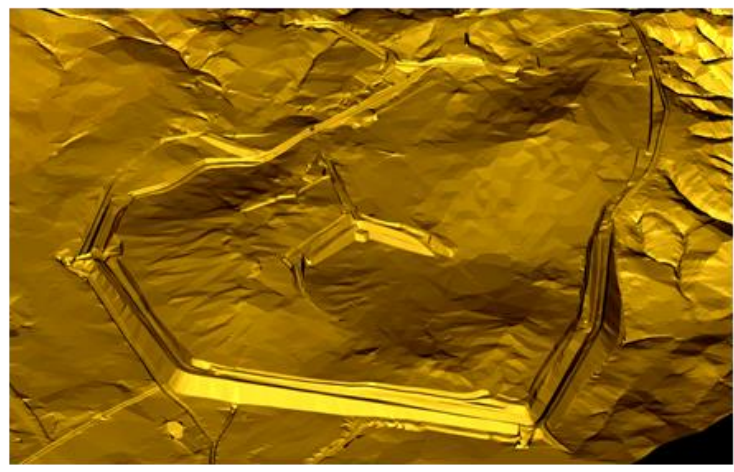

Aug 2006 beach extension of Southern and establishment of South Eastern mounds

\section{Figure 14 Sequence of survey renders showing development of the trial mounds}

\subsection{Storm management}

Raising the embankments hydraulically using advancing cones introduces storm water management issues since there is runoff from the slope face to the outer parts of the TSF. To accommodate and control this storm water, storm water control trenches were constructed along and on the inside of the existing toe starter embankments, as indicated in Figure 15, which also shows the locations of spillways which enable the water to be discharged at ground level and directed to the reclaim pond located to the immediate south of the TSF. 


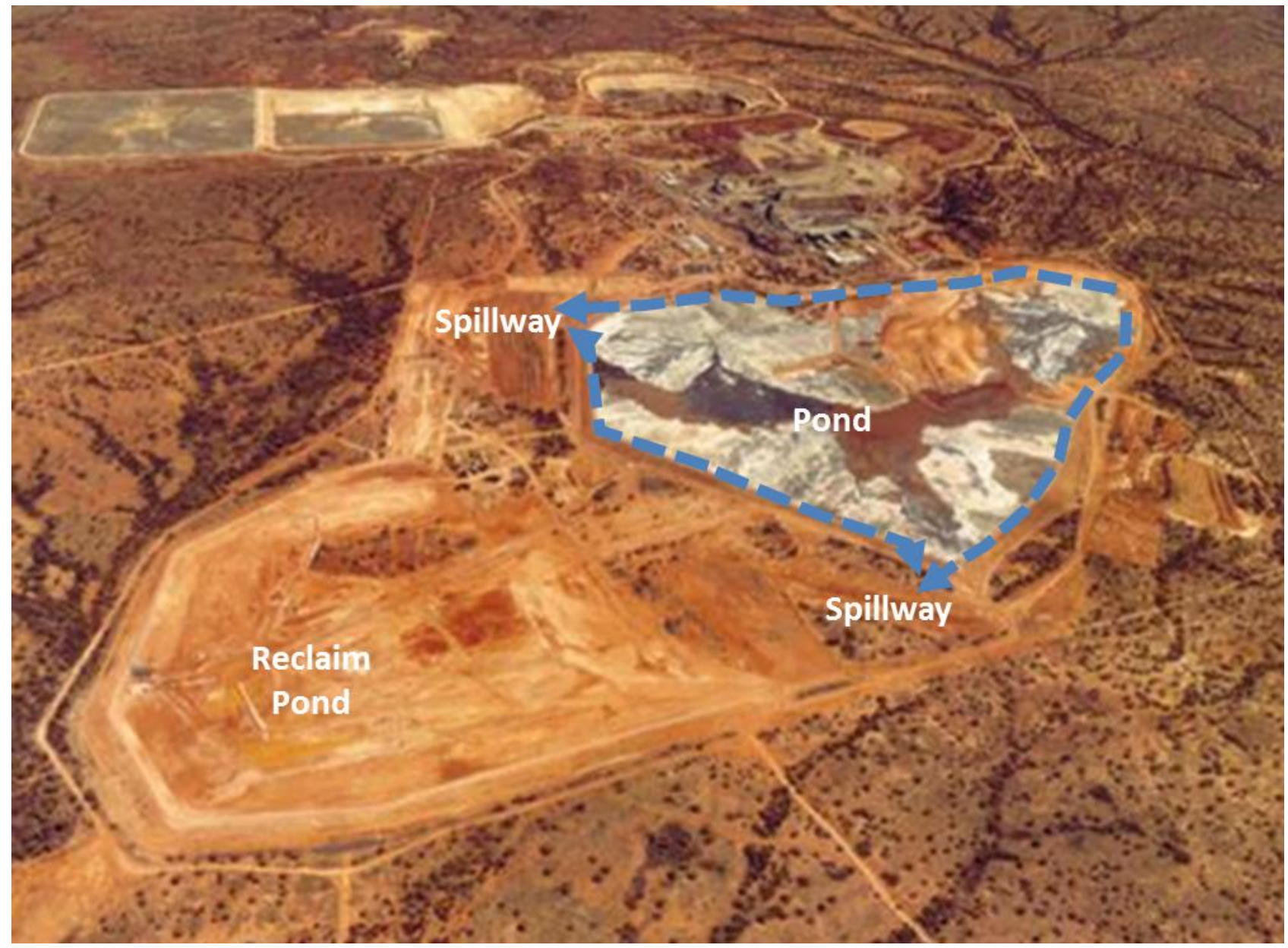

\section{Figure 15 Location of storm management trenches and spillways}

\section{$5 \quad$ Tailings geotechnical assessments}

In the course of the trial, samples were collected from the tailings beach and submitted for geotechnical testing to Pretoria University where particle-size distributions were determined and stress path and consolidation testing were carried out. In addition, field density tests were conducted by local laboratory personnel. The following sections summarise pertinent results.

\subsection{Critical state testing}

A vital issue for the regulator, in respect of the method of placement of the thickened tailings, is that of the liquefaction induced by slope failure. It is common to assess liquefaction potential by determining whether the material is contractive. Stress path testing in the method described by Papageorgiou (2003) was conducted.

Stress path testing confirmed that the tailings could be contractive if at sufficiently high void ratio. The tests were conducted on loose hand-tamped samples, saturated, consolidated and then tested undrained with pore pressure measurements. Figure 16 shows the stress paths for tests at a range of initial densities and Figure 17 shows the initial and final void ratios, as well as the derived critical state line. 


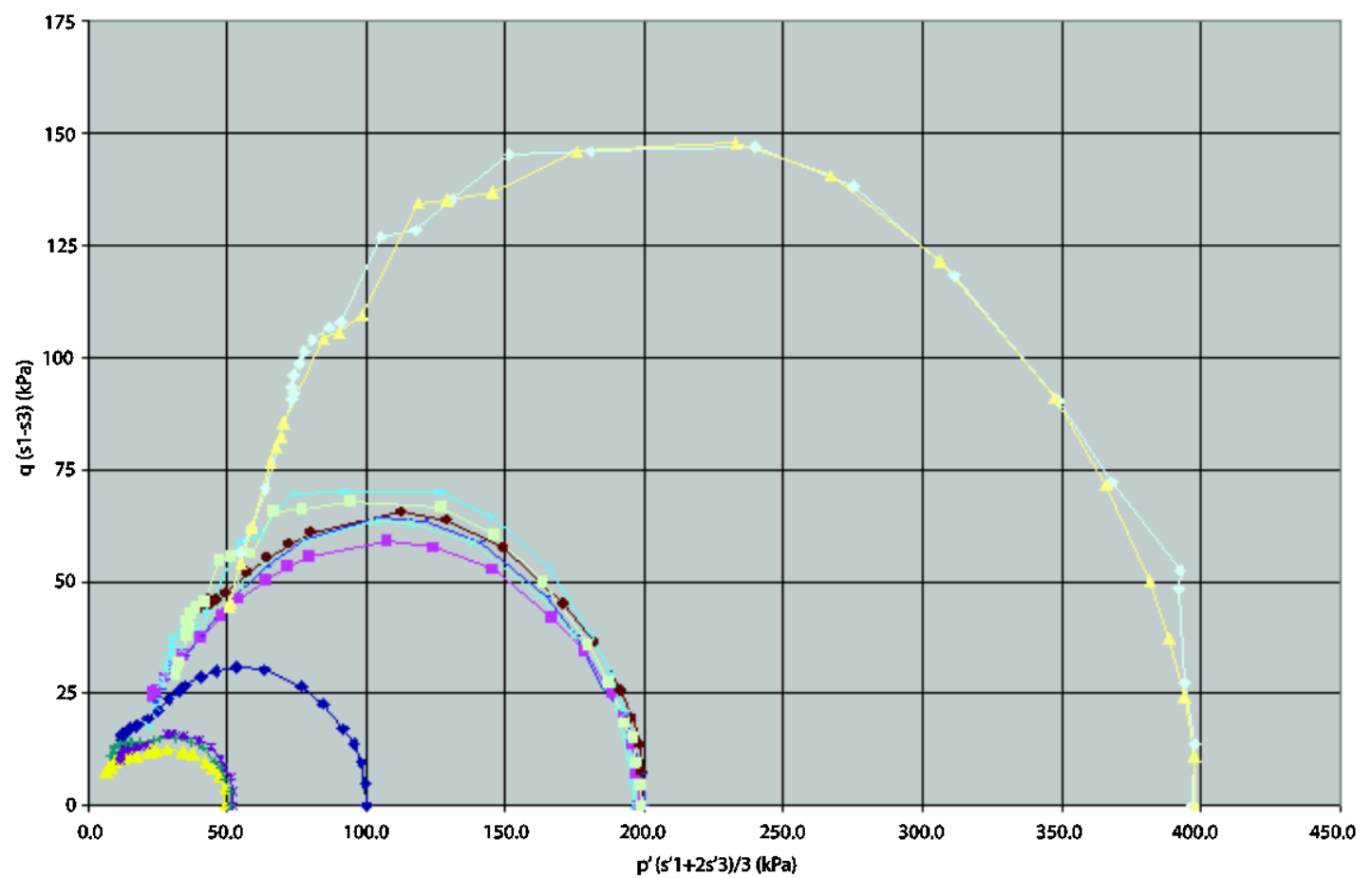

\section{Figure 16 Stress path testing at a range of initial densities}

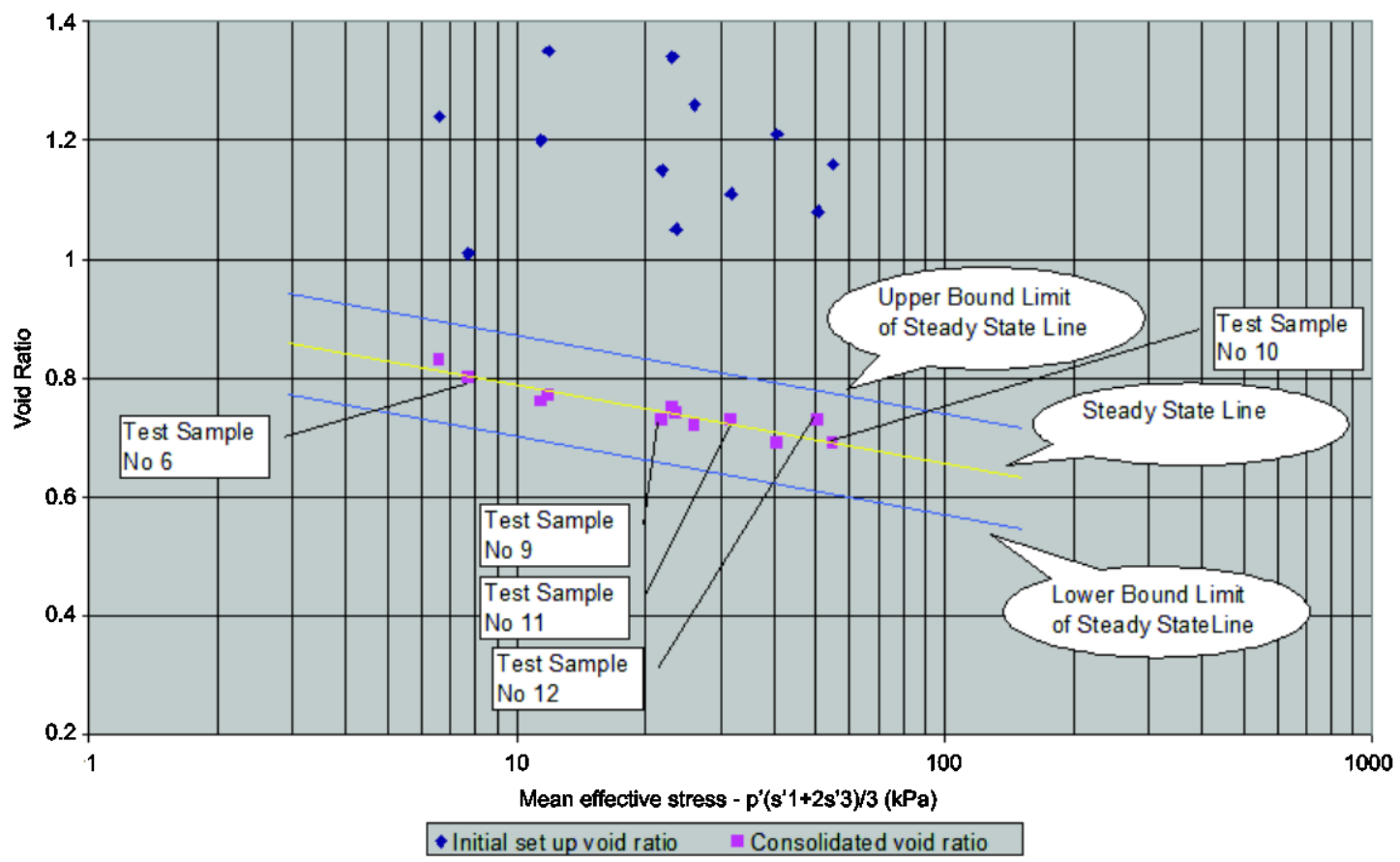

\section{Figure 17 Critical state line}

Tailings at stress and void ratio state that the plot below the envelope (Figure 17) is considered dilatant, whereas those that plot above the envelope are considered contractive. Tailings that plot within the envelope are considered semi-contractive. 


\subsection{Rowe cell testing}

To assess the likely stress state of an initially slurried sample of tailings undergoing drained consolidation, testing was conducted in a Rowe cell. This approach allows the determination of consolidation coefficients and permeabilities at a range of stress states and also allows the determination of the consolidated void ratio at each stress.

Figure 18 shows void ratio versus square root of time plots for an initially slurried sample of tailings from which the coefficient of consolidation and the permeability at each stress state were determined, as indicated in Table 1.

Figure 19 shows the consolidation curve for the initially slurried sample.

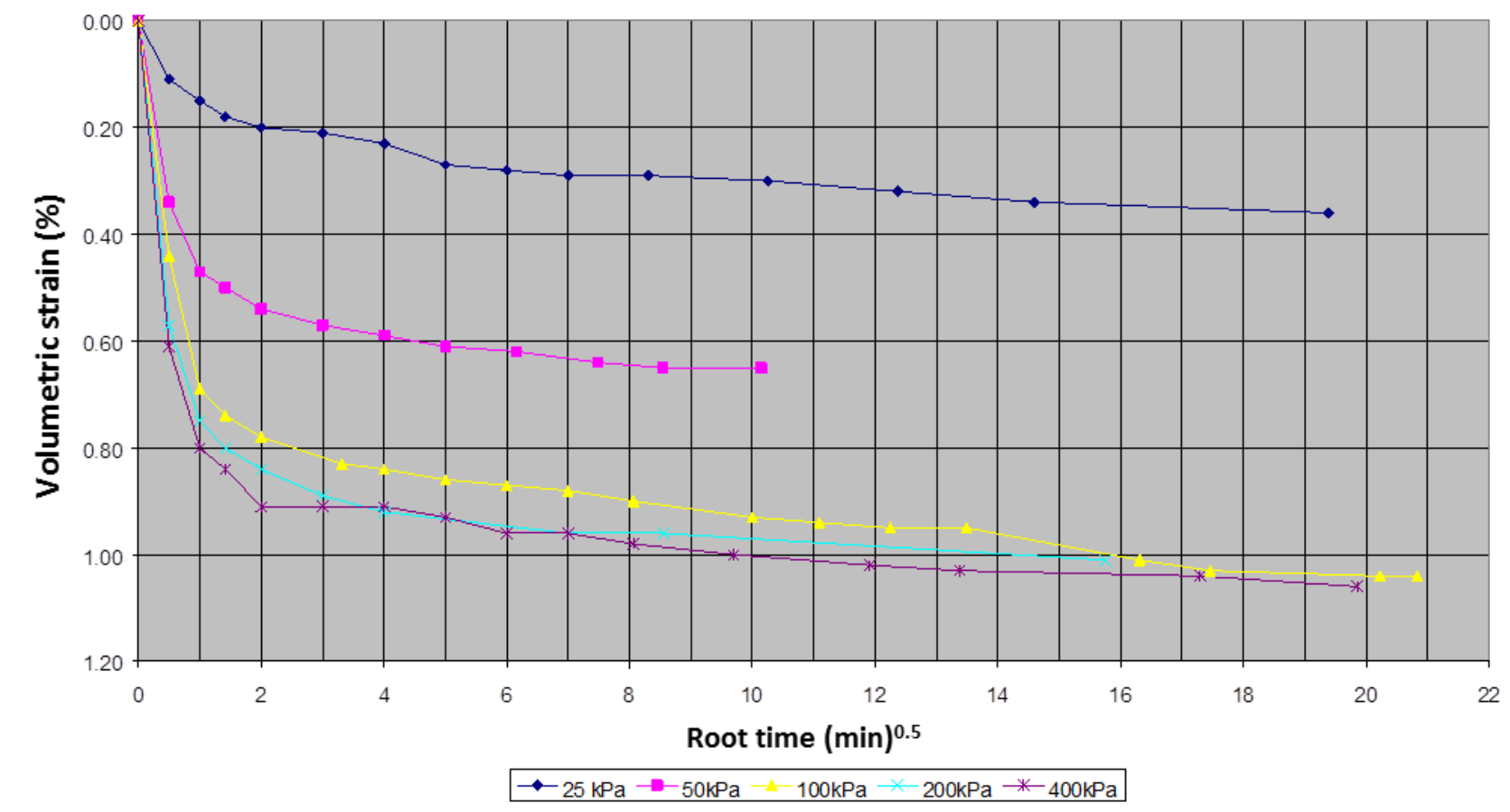

Figure 18 Void ratio versus root time curves from the Rowe cell 


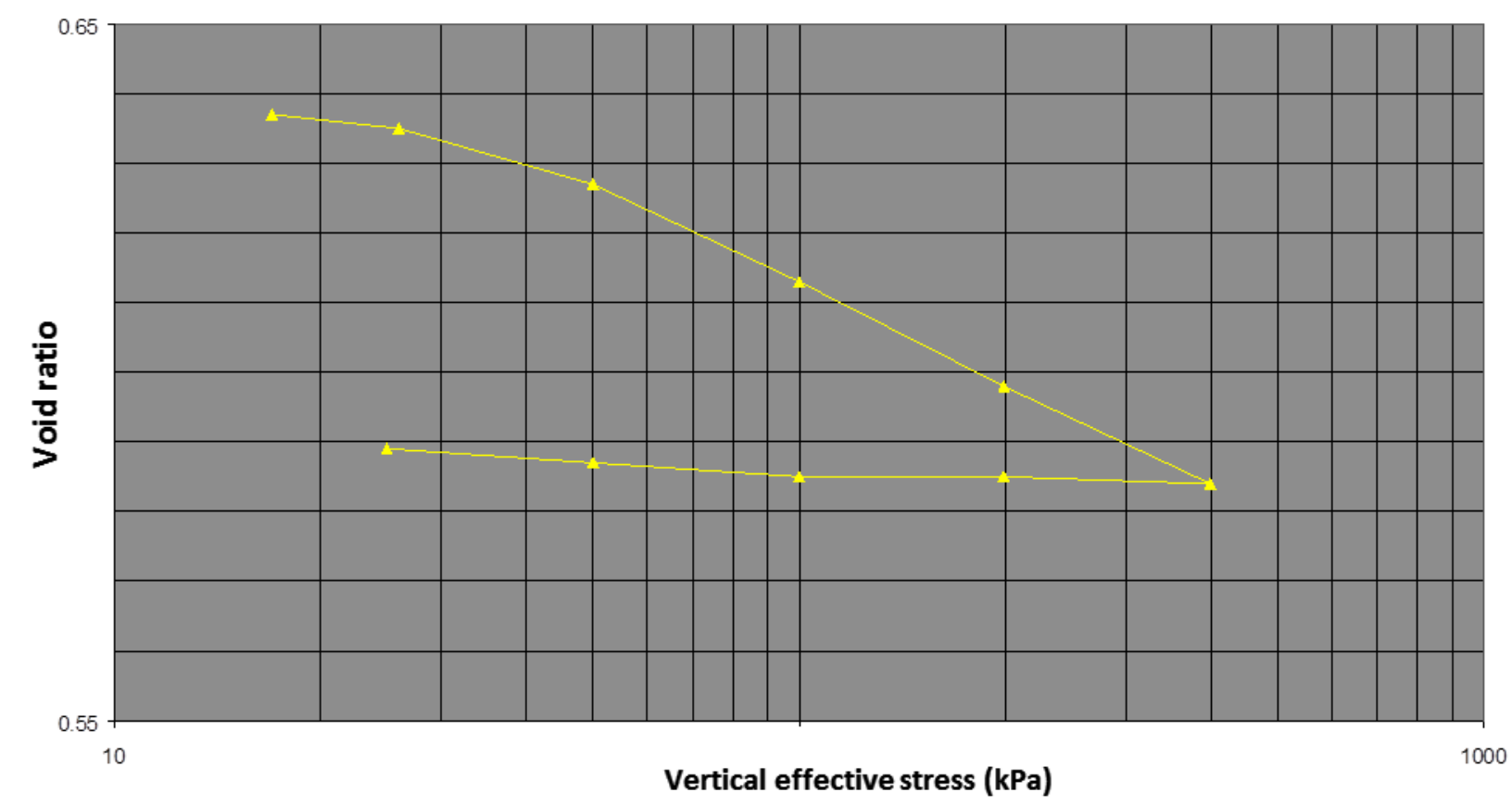

Figure 19 Consolidation curve from the Rowe cell

Table 1 Coefficients of consolidation and permeabilities from the Rowe cell tests

\begin{tabular}{cccc}
\hline $\begin{array}{c}\text { Vertical } \\
\text { effective stress } \\
(\mathbf{k P a})\end{array}$ & $\begin{array}{c}\mathbf{t 9 0} \\
(\mathbf{m i n})\end{array}$ & $\begin{array}{c}\mathrm{Cv} \\
\left(\mathbf{m}^{2} / \mathbf{y}\right)\end{array}$ & $\begin{array}{c}\mathbf{k} \\
(\mathrm{m} / \mathrm{s})\end{array}$ \\
\hline 25 & 0.77 & 13,362 & $8.5 \times 10^{-7}$ \\
50 & 1.32 & 7,736 & $4.9 \times 10^{-7}$ \\
100 & 1.42 & 7,224 & $3.9 \times 10^{-7}$ \\
200 & 1.27 & 8,083 & $2.4 \times 10^{-7}$ \\
400 & 1.39 & 7,347 & $1.0 \times 10^{-7}$ \\
\hline
\end{tabular}

The following points are noteworthy, given the fine-grained nature of the tailings:

- The coefficients of consolidation are high, indicating that the tailings drain well. This is in line with in situ observations.

- The permeabilities are relatively high - approaching that for a fine-grained sand at low stress levels.

\subsection{Lab-based assessment of liquefaction potential}

To assess the liquefaction potential of the tailings, the consolidation test results were plotted together with the critical state points (Figure 20). The vertical stress in the consolidation test was used to determine the parameter $p^{\prime}$ using the following equation:

$$
p^{\prime}=\left[\sigma_{v}{ }^{*}\left(1+2 K_{0}\right)\right] / 3
$$

Where:

\footnotetext{
$\sigma_{v}{ }^{\prime}=$ vertical effective stress in the odometer.

$\mathrm{K}_{0}=$ coefficient of earth pressure at rest, which is equal to 0.425 for an effective angle of friction of $32^{\circ}$, a value representative of the tailings based on past testing.
} 


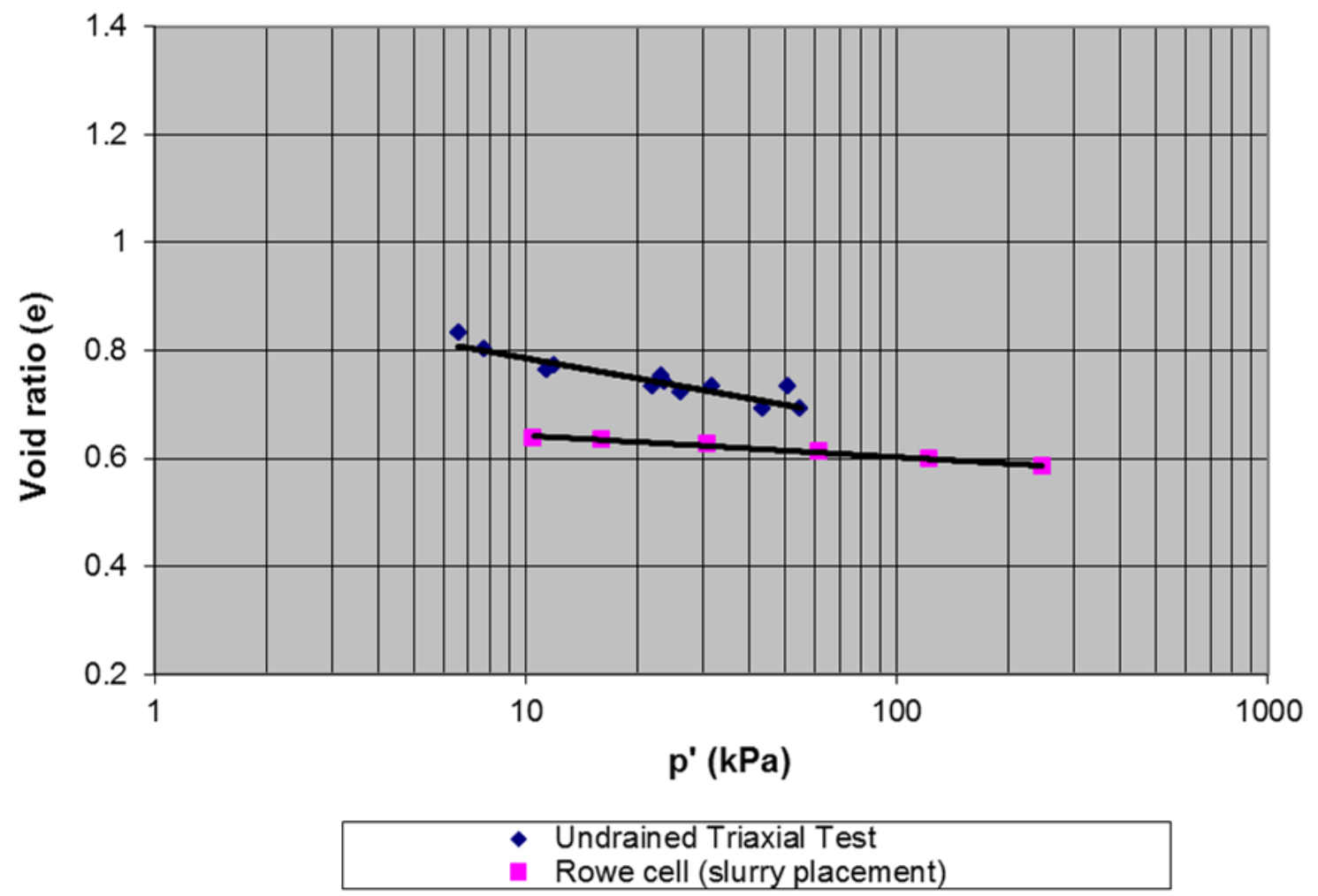

\section{Figure 20 Plots of the critical state and the 1D consolidation data}

It is evident from Figure 20 that:

- The slurried sample is in the dilatant range stress state from the outset of the consolidation test.

- The slurried sample enters the semi-contractive range at a $\mathrm{p}^{\prime}$ of $80 \mathrm{kPa}\left(\sigma_{\mathrm{v}}{ }^{\prime}=130 \mathrm{kPa}\right.$, which at a density of $2.2 \mathrm{t} / \mathrm{m}^{3}$ is approximately $6 \mathrm{~m}$ of tailings).

- An extrapolated consolidation line meets an extrapolation of the critical state line at $p^{\prime}=500 \mathrm{kPa}$ ( $\sigma_{\mathrm{v}}{ }^{\prime}=810 \mathrm{kPa}$ which at a density of $2.2 \mathrm{t} / \mathrm{m}^{3}$ is approximately $37.5 \mathrm{~m}$ in height).

- Since the maximum tailings slope height will be less than $37.5 \mathrm{~m}$, the tailings are unlikely to cross the extrapolated intersection point and will therefore, at worst, exist in a semi-contractive (but nonetheless dilatant) state.

Based on the above it was deduced that the tailings are unlikely to liquefy within the stress range of the TSF.

\subsection{Field-based assessments}

To verify the consolidation parameters measured in the lab, as well as provide a check on the piezometer measurements, four piezometer cone soundings were carried out in the tailings at the locations indicated in Figure 11. The results for the soundings at the deepest tailings locations are shown in Figures 21 and 22. 


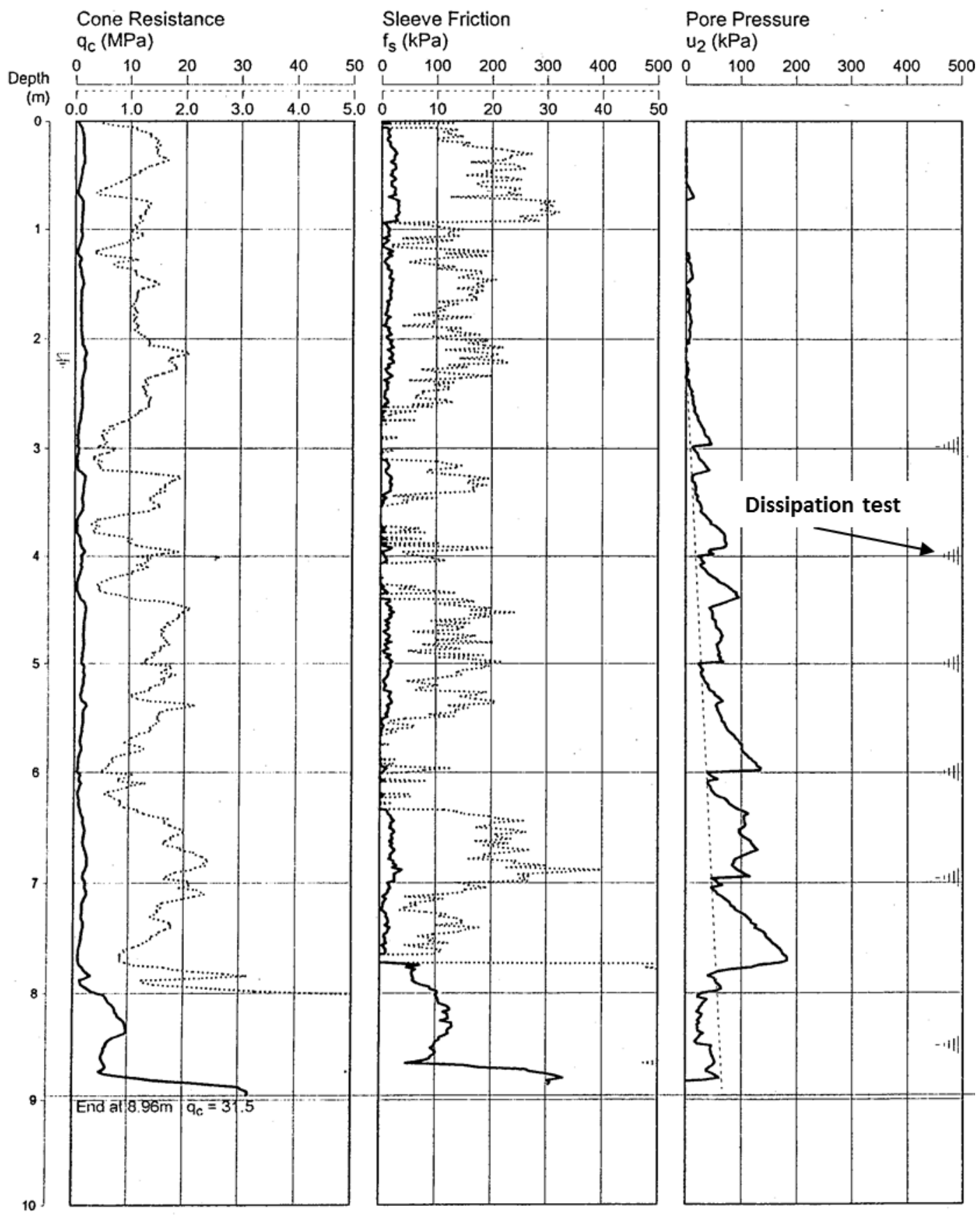

Figure 21 Piezometer cone sounding results at a location $\mathbf{4 0} \mathrm{m}$ behind the crest point 


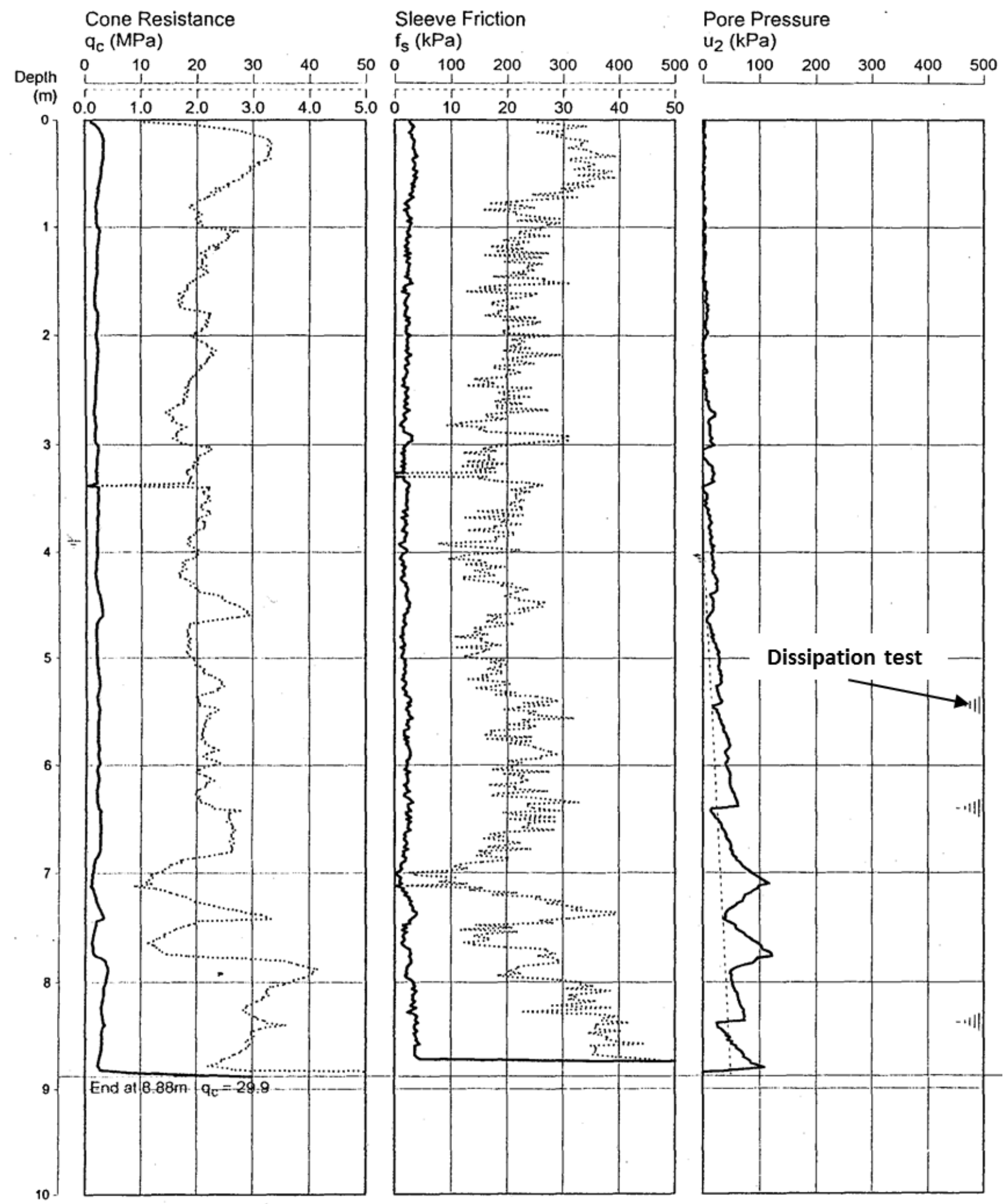

Figure 22 Piezometer cone sounding results for a test at the crest point

The following points are noteworthy from an assessment of the piezometer cone results:

- There is no sign of excess pore pressure.

- Dissipation rates are similar to those measured in the Rowe cell, which indicates that the lab test is reasonably representative of the field situation.

- Water pressures in the slope are in reasonable agreement with the standpipe piezometers. 
The cone resistance is greater than $0.5 \mathrm{MPa}$ and, in the case of the sounding at the crest point, is generally $2 \mathrm{MPa}$. It is interesting to note the soft zones in the sounding back from the crest. This is attributed to variations in the slurry in the course of the trial.

\subsection{Slope stability assessments}

Application of the consolidation and seepage data to slope stability analyses has shown that Factors of Safety (FS) are above 2 and probabilities of failure below 1 in 10,000, even for very conservative assumptions on pore pressures, drainage conditions and shear strength. This is in keeping with the flat slope angles that are generated by the thickened tailings mound.

\subsection{Erosion parameter assessments}

Erosion of the beaches of tailings placed at $50 \%$ solids is known to be very low. On the other hand, thickened tailings result in considerably steeper beaches and the question of erosion of these slopes, both during operation and after decommissioning, needs to be assessed. To this end, erosion testing and modelling have been carried out. The erosion testing has been carried out using a rainfall simulator which has been designed to ensure that the kinetic energy transmitted by the simulated rainfall is similar to natural rainfall. Gullying is assessed by over-land flow tests. Figure 23 shows the testing on both tailings, as well as material that would be used as topsoil or 'growth medium'. In both test types, sedimentation samples are collected at short time intervals and the flow rates accurately measured.
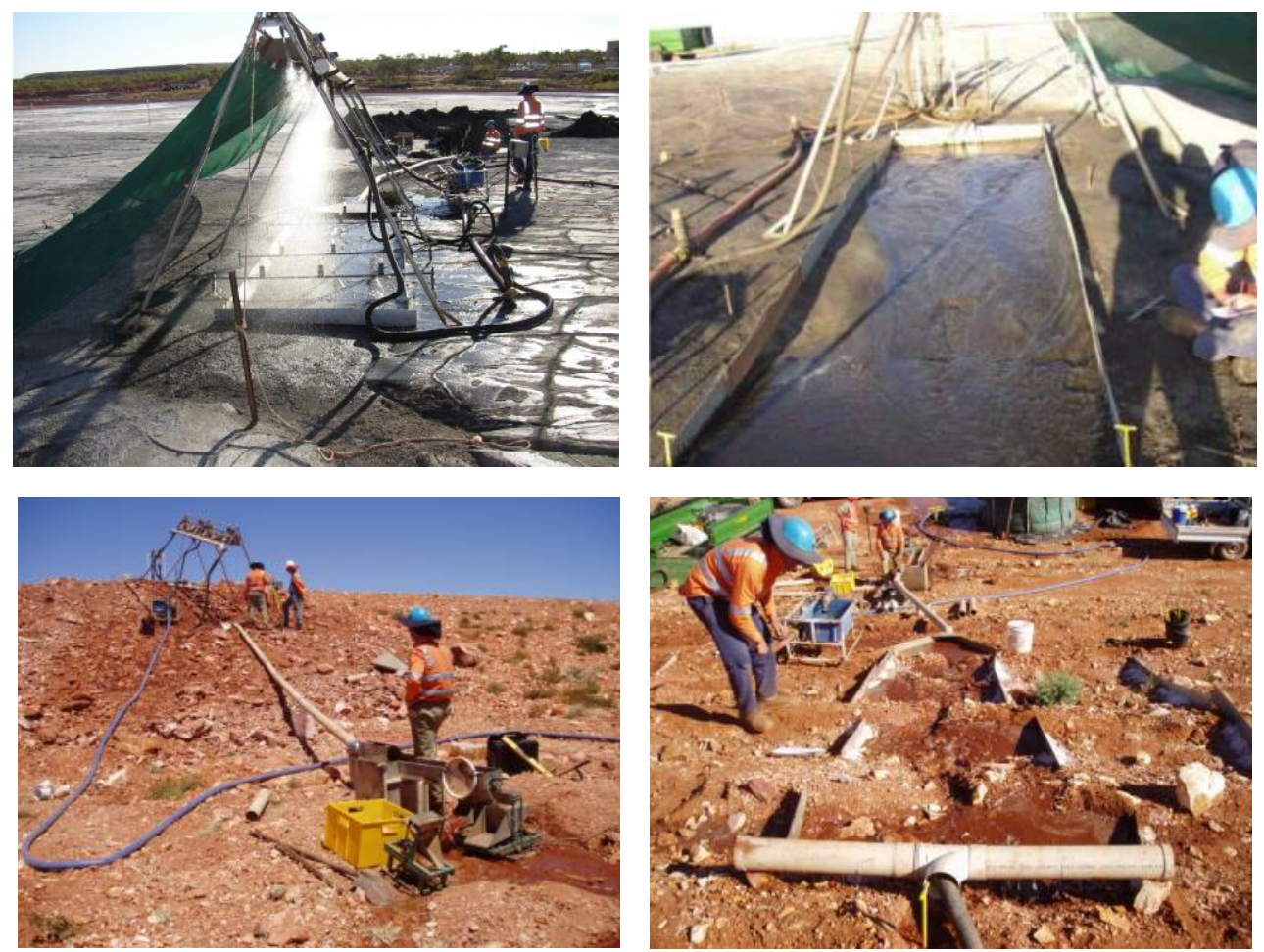

\section{Figure 23 Rainfall and gulley erosion simulations. Top is tailings and bottom is growth medium}

The results of the field measurements have been used to derive erosion parameters that have been applied in the dynamic erosion modelling program SIBERIA (Willgoose 1989). SIBERIA models long-term landform evolution and works with a digital terrain model (DTM) of the surface. The DTM is adjusted with each iteration in the simulation which means that the model is able to simulate gulley formation. 


\section{$6 \quad$ Tailings operation experiences}

Production of the HDTT was effected using the available $9 \mathrm{~m}$ high rate thickener at Osborne in combination with a nest of cyclones which were originally installed at the time of mine commissioning to generate underground backfill but had never been used. Overflow from the cyclone nest is directed to the thickener and underflow from the thickener is combined with the underflow from the cyclone nest at a pump sump. A process flow diagram of cyclone/thickener circuit is shown in Figure 24 and a photo of the setup is shown in Figure 25.

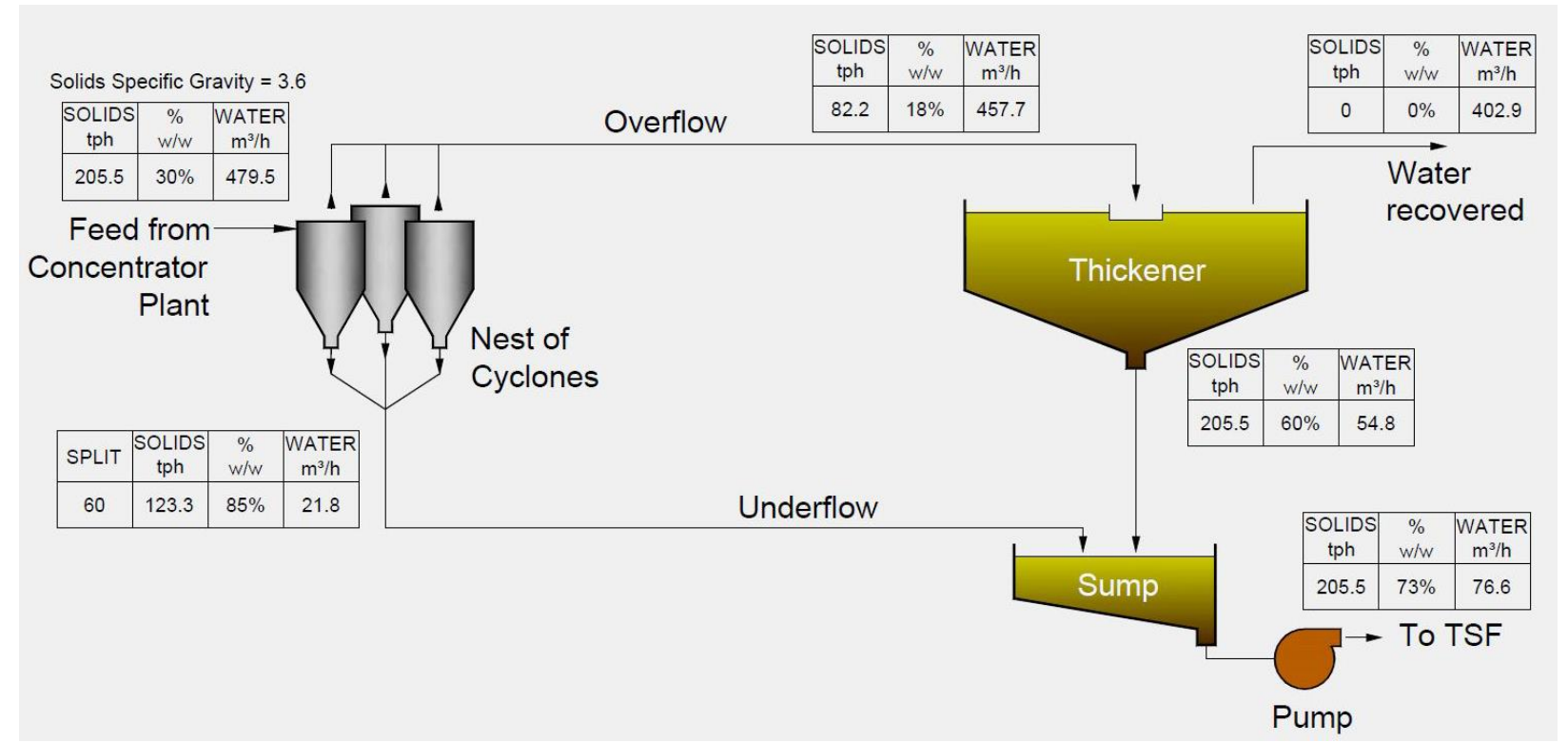

\section{Figure 24 Process flow diagram for Osborne HDTT}

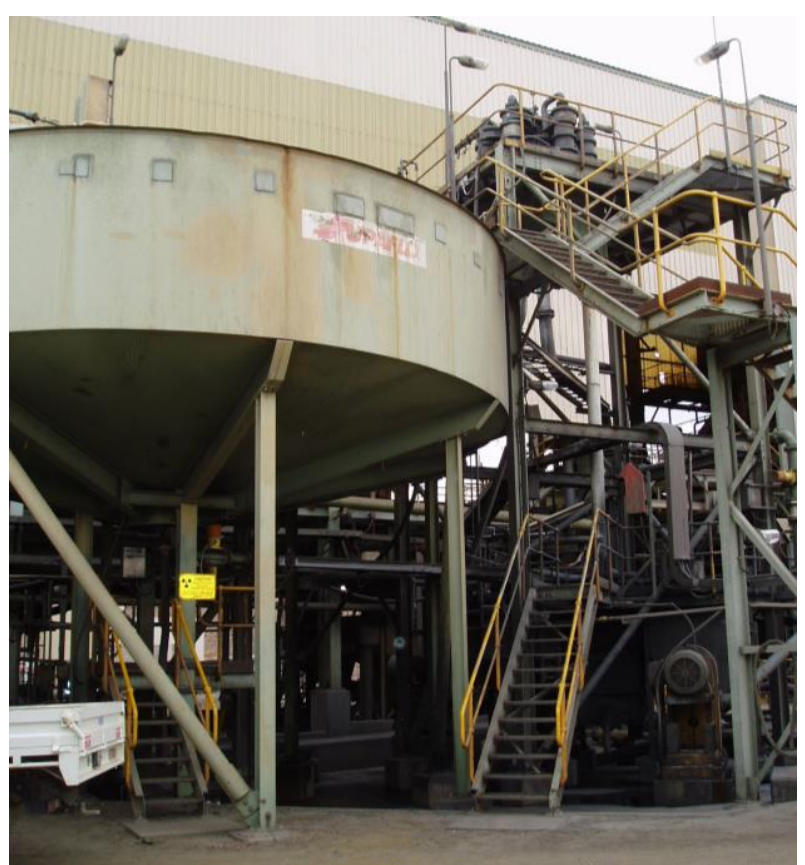

\section{Figure 25 Cyclone and thickener to generate HDTT at Osborne}

\subsection{Plant and equipment changes to effect HDTT}

A summary of the modifications to the plant which were made to allow production of high-density tailings were as follows: 
- Tuning of all control loops from grinding through floatation and tailings to allow stable operation at desired density.

- Reduction in tailings cyclone spigot sizes from 70 to $57,51,47,45$ and $41 \mathrm{~mm}$ to increase underflow density and send more solids to the thickener.

- Increase of the tailings thickener feedwell deflector cone gap from 140 to $280 \mathrm{~mm}$ to handle increased flow to the thickener.

- Modifications to the thickener underflow cone and piping to remove obstructions and allow freer gravity flow of underflow stream.

- Installation of higher ranging bed mass gauge in thickener.

- Installation of density gauges in the thickener underflow line and tailings pipeline to allow closer monitoring of operation and targeting of specific densities.

- Change of flocculant product to better suit duty and allow higher density underflow.

- Installation of second flocculant sparger in the thickener feedwell.

- Installation of flow meter in the thickener underflow line.

No additional thickening equipment was required.

\subsection{New dam pumping and piping system}

The pumps provided for transferring the HDTT from the thickener circuit to the TSF are centrifugal with mechanical seals. Two stages have been sufficient to date.

Several aspects of the new pumping and piping system for TSF2 were designed specifically to suit the pumping and deposition of high-density tailings. These included:

- Design of the pipeline diameter and pressure rating to suit both HDTT as well as 'normal' density.

- Installation of flow meters at the plant as well as at the valving station on the dam wall to give an indication of line blockages and ruptures.

- Installation of a pressure gauge at the valving station.

- Increasing the capacity of the flushing system to allow the delivery lines to be cleared.

- Installation of a camera to monitor flow from spigots.

- Installation of a by-pass tailings pipeline to minimise the impact of potential line blockages.

\subsection{Operational changes}

The production and deposition of high-density tailings required a number of operation changes and strategies had to be developed to minimise the potential for line blockages, as well as allow for efficient deposition. Some of these changes and strategies are as follows:

- Operating the thickener with a higher bed mass and flocculant dosage.

- Operating the tailings hoppers at low levels to prevent a build-up and subsequent slumping of solids in the hoppers.

- Increased monitoring of operations with respect to densities, flows and pressures.

- Installation of a delivery pipeline flushing point as close as practical to the deposition point to allow flushing of the line without excessive scouring of the high-density beach. The entire line can then be flushed to this point, after which only a brief flush of the spigot is required. 
- Diverting the flow at a high-density spigot should the density fall so that the low density discharge does not scour the beach. This occurs immediately if the plant is shut down unexpectedly or if some major change occurs; it also happens if the density drifts low for around half an hour and efforts to increase the density are unsuccessful.

- More regular monitoring and replacement of tailings cyclone spigots to ensure optimum density is maintained.

- Operational strategies to increase the tailings density if it drops due to operation of the cyclones. A cyclone in the nest is turned off if possible, or if not possible then a combination of cyclones with smaller spigot diameters is brought on line. The bed mass in the thickener can also be raised and the flocculant dosage increased.

\subsection{Performance}

The performance of the plant while processing Osborne ore was reasonably steady, with percent solids between 72 and $76 \%$ being obtained for the majority of the time. Occasionally there was difficulty in maintaining density which was attributed to variability in the ore.

While the pipe loop test-work allowed the pumping pressures required to be predicted, when these pressures were compared with measurements while effecting trial depositions on TSF1, the predicted pressures were found to be too high. A number of iterations of calculations were conducted after which a scale-up factor from the pipe loop test-work was derived (0.38). The predicted pressures using this scaling factor matched very closely with those measured after commencing pumping to TSF2.

The predicted pressure drops after applying the scaling factor were in the range of 0.28 to $0.46 \mathrm{kPa} / \mathrm{m}$ in the density range of 68 to $75 \%$ solids. These correspond to pressures of around $400-680 \mathrm{kPa}$ at the furthest spigot, which were within the range of the operating measurements. The test-work indicated that at densities exceeding $76 \%$ solids, pumping performance would drop markedly with pressure drop per metre increasing rapidly. This was validated by operational experience. If the density increased above around 76-78\% solids, for any length of time, then the flow rate in the pipeline dropped and the pipe started to sand up. If this was not noticed and remedied quickly, the line would choke completely and the emergency pipeline would have to be brought online while the duty line was flushed. This occurred several times, but it has always been possible to clear the duty line by flushing water; it was not necessary to dismantle the line to allow clearing.

\subsection{Water savings}

Implementation of HDTT over the trial period proved that significant reductions in water loss are achievable (Figure 26), which shows that the specific water usage reduced from approximately $0.5 \mathrm{~m}^{3} / \mathrm{t}$ of ore processed to approximately $0.3 \mathrm{~m}^{3} / \mathrm{t}$ of ore processed. This translated into a reduction in average borefield abstraction from 81 to $51 \mathrm{~m}^{3} / \mathrm{h}$; i.e. a reduction of $37 \%$ based on a percent of $75 \%$, which was being achieved over the trial. 


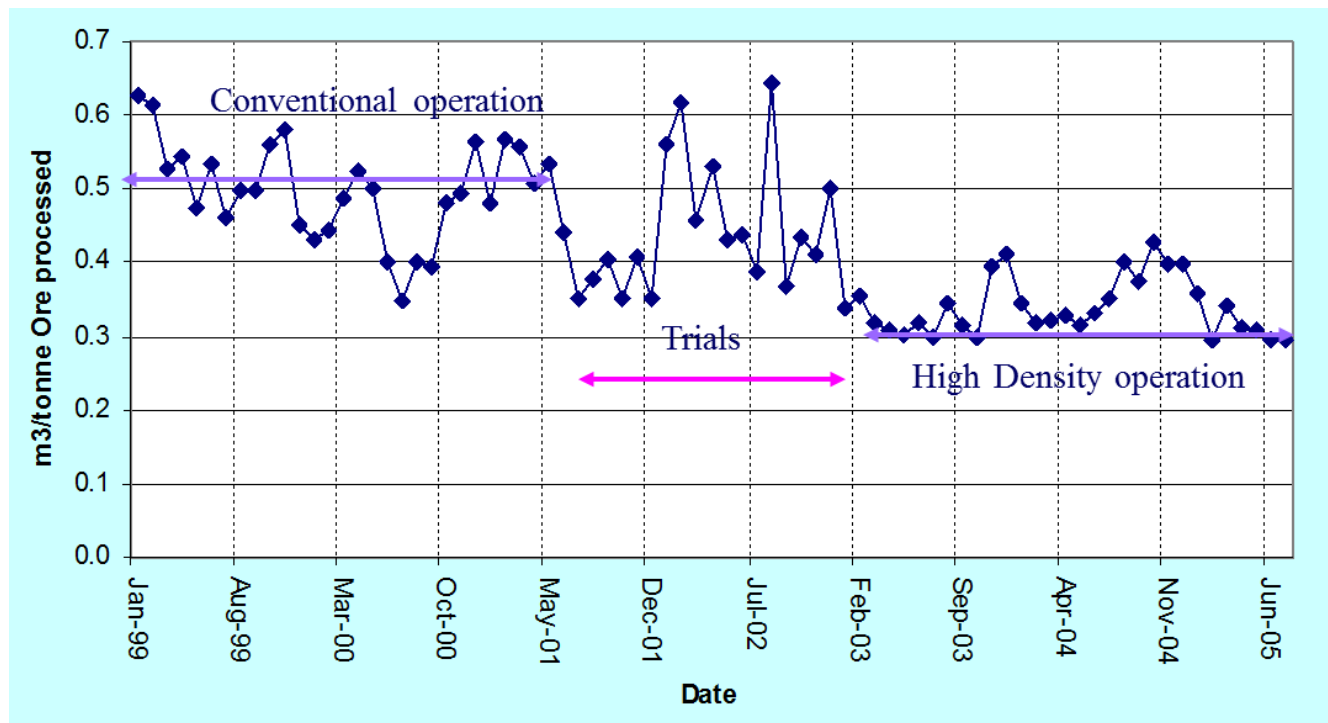

\section{Figure 26 Specific water usage pre and post commissioning of HDTT}

\subsection{Summary of operating benefits}

The benefits of HDTT at Osborne have included:

- The elimination of lifts to confining embankments. Since these lifts commonly cost of the order of AUD $2 \mathrm{M}$ and are repeated every two to three years, elimination of the lifts represents a very significant cost saving.

- A higher placed density for the tailings.

- A reduction in water losses.

- Lower seepage - piezometers show the water table within the TSF to be at foundation level even though the tailings are some $20 \mathrm{~m}$ in thickness.

- An improvement in terms of responsible environmental behaviour and a reduction in post-closure costs until the level in the artesian aquifer is restored.

- A reduction in return water pumping volumes and energy.

- An opportunity for progressive rehabilitation of the final tailings landform as a result of the advancing cone method of formation.

\section{$7 \quad$ Operations from 2006 to 2015}

In 2006, ore from Osborne began to be supplemented with ore from satellite mines. Initially ores were batch processed resulting in significant changes in slurry characteristics when the non-Osborne ore was being processed. Beaches flattened from 1:30 to 1:60, mainly due to the mineralogical differences in the ore. This was addressed through a number of actions:

- Ore blending and elimination of batch processing so as to dilute the impact of the ores from the satellite pits.

- Flocculation testing to identify alternative flocculants and dosages to improve the thickening of the cyclone overflow materials.

- Splitting of the flow at the discharge end of the pipe into three nearly equal discharges and ensuring that the smaller discharges were a minimum of $20 \mathrm{~m}$ apart so as to reduce the probability of the flows re-combining down the beach. 
The aforementioned measures were effective in bringing the beach slope back to 1:40 to 1:45, depending on the satellite pit ore being blended and processed.

Figure 27 shows survey renderings of TSF from 2006 to 2012 and the modelled deposition to 2015.
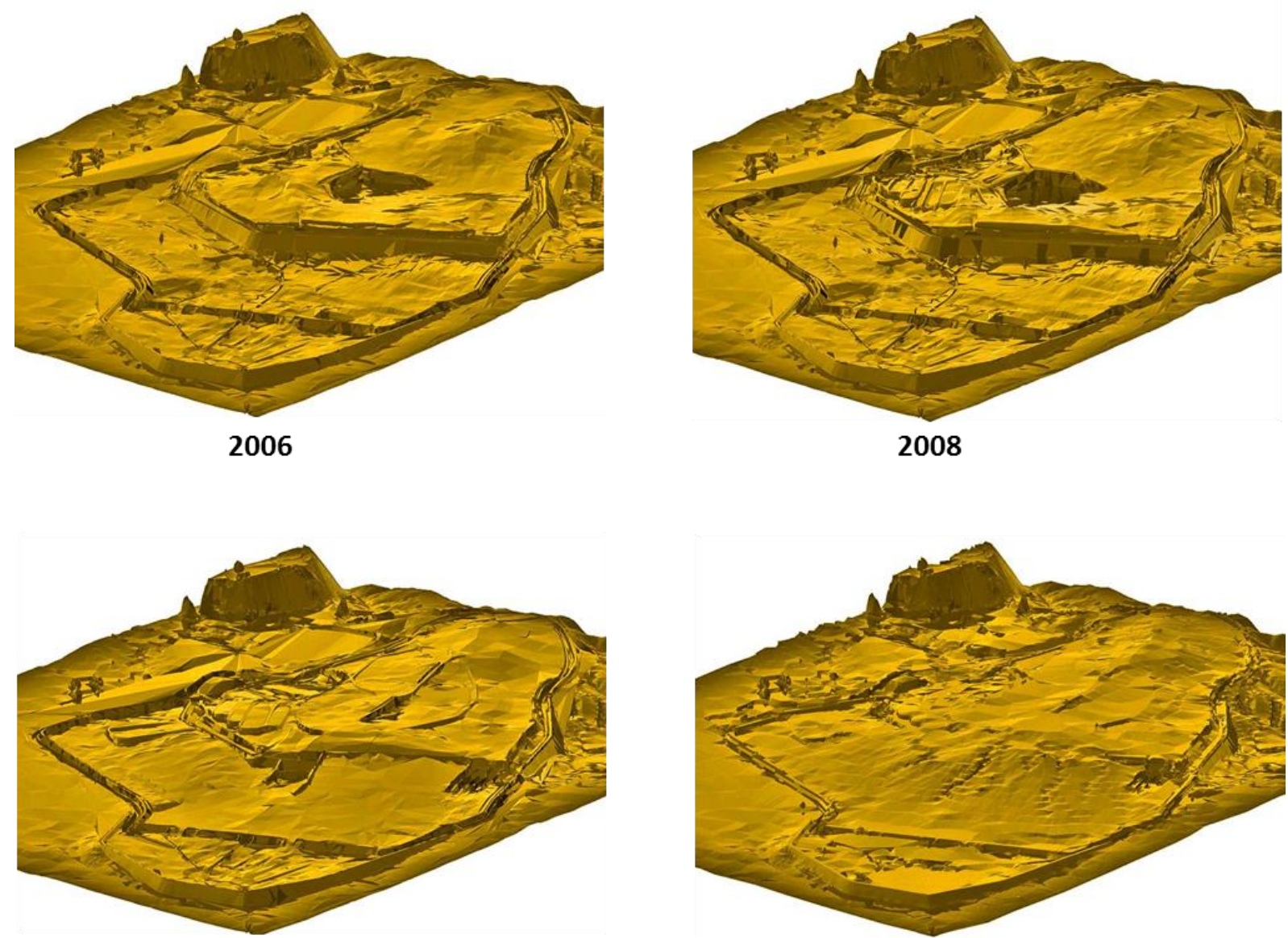

2009
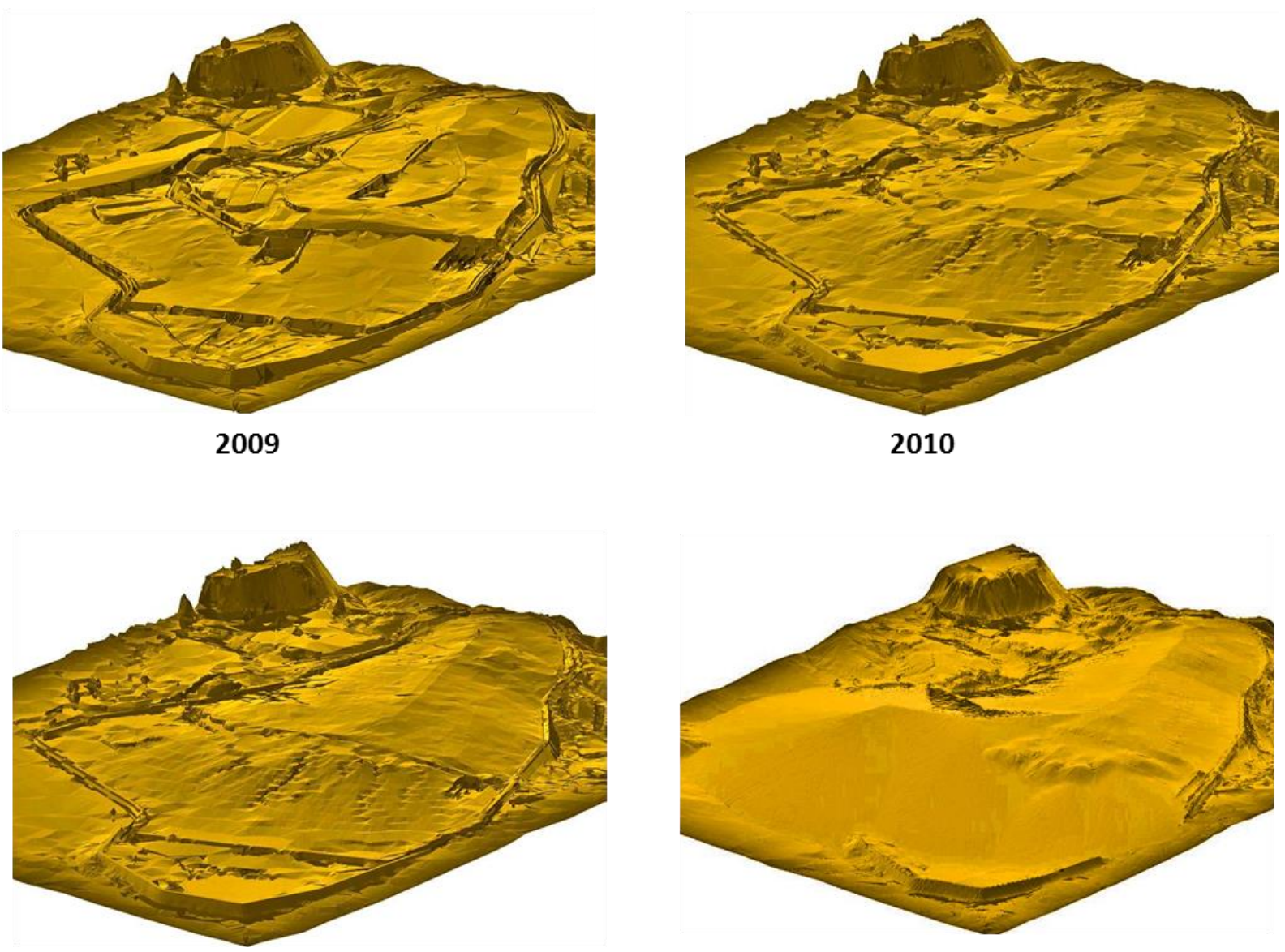

2012

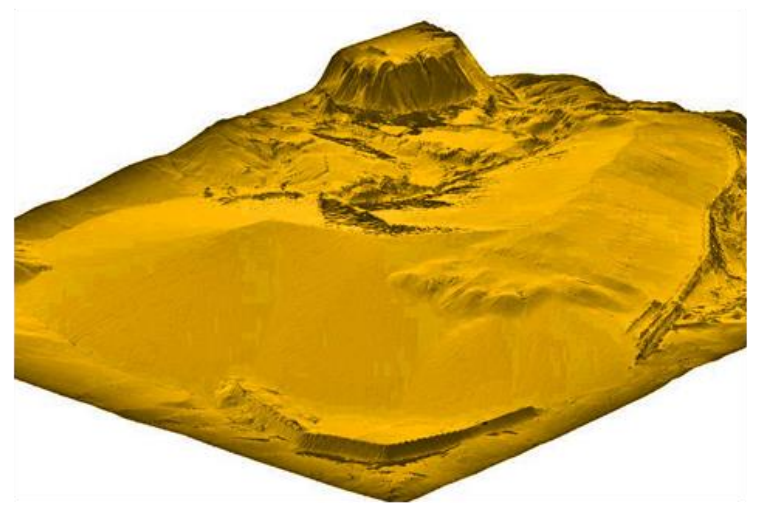

Modelled 2015

\section{Figure 27 Survey renderings of TSF2 2006 to 2012 together with the modelled rendering for 2015}

Figure 28 shows an aerial photograph of the facility as at October 2014. The reclaim pond is in the foreground. 


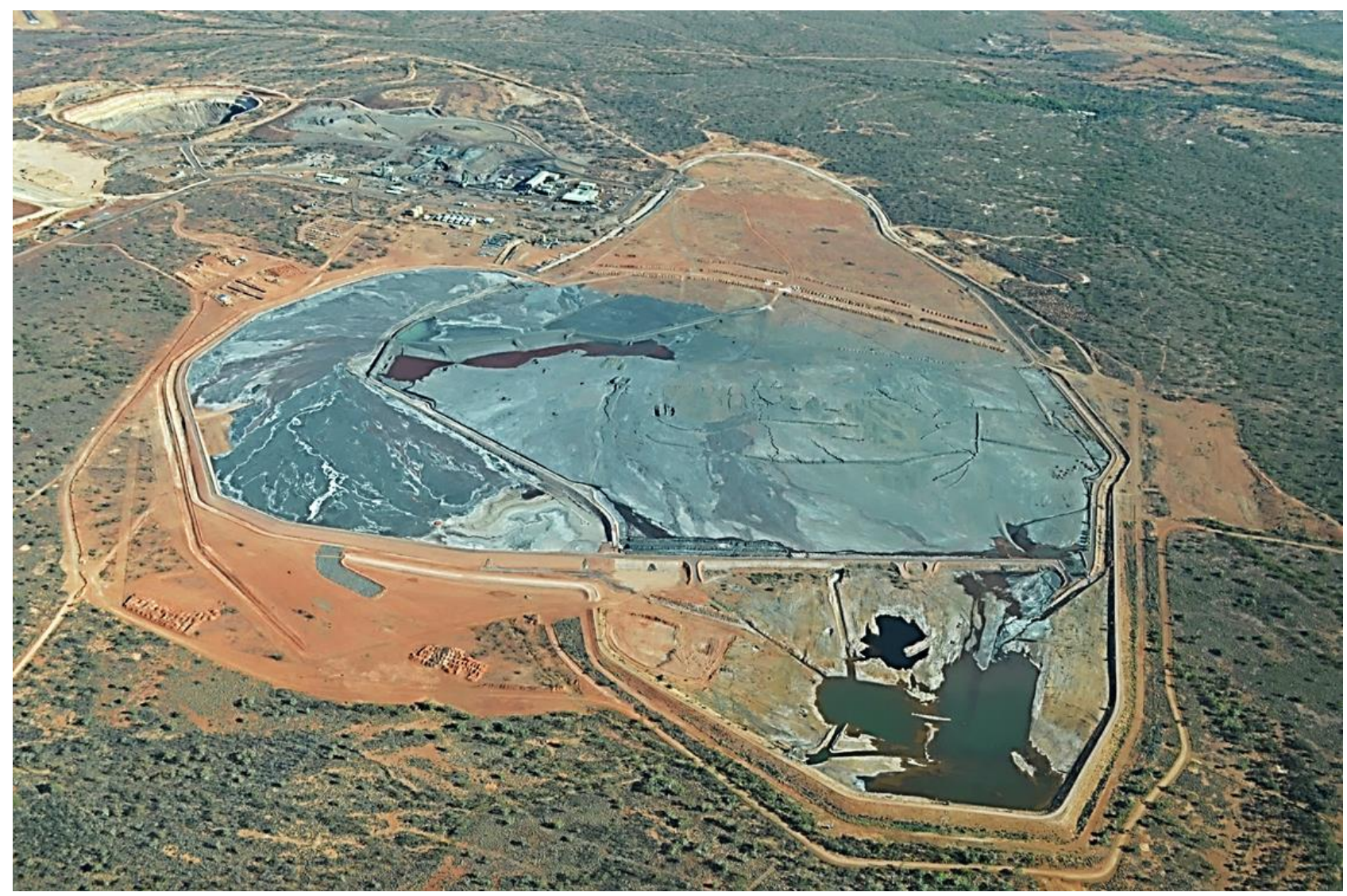

\section{Figure $28 \quad$ Aerial photo of TSF2 as at October 2014}

\section{$8 \quad$ Closure planning}

\subsection{Cover trials}

In October 2009, the top surface of part of TSF1 was covered with a trial 'store-and-release' closure cover made up of two layers:

- A capillary break layer consisting of $0.5 \mathrm{~m}$ of coarse-grained silcrete material - intended as a buffer layer to reduce salt uptake from the tailings into the next layer.

- A 'store-and-release' soil layer over the capillary break layer consisting of $0.6 \mathrm{~m}$ of topsoil or growth medium (identified as silty sand with some gravel size material) thickening to $1.4 \mathrm{~m}$ around the decant structure.

The cover was instrumented using suction sensors and thermistors in several locations and has been monitored since January 2010, so as to observe the performance of the trial cover. Three annual reviews of the instrumentation readings have been conducted and water balances for the cover developed so as to estimate the net percolation through the cover. A net percolation of $11 \%$ of the annual rainfall has been derived. This is deemed a practical estimate of the net percolation and has been carried forward to TSF2.

\subsection{Effectiveness of the capillary break layer}

In 2010, as part of a mine sale transaction, the northern part of TSF2, an area of some 58 ha opposite the processing plant (Figure 29) was covered with a single layer of silcrete principally for dust control purposes. The material in this layer is similar to that which would be used as a capillary break and varies in thickness from 0.3 to $0.6 \mathrm{~m}$. 


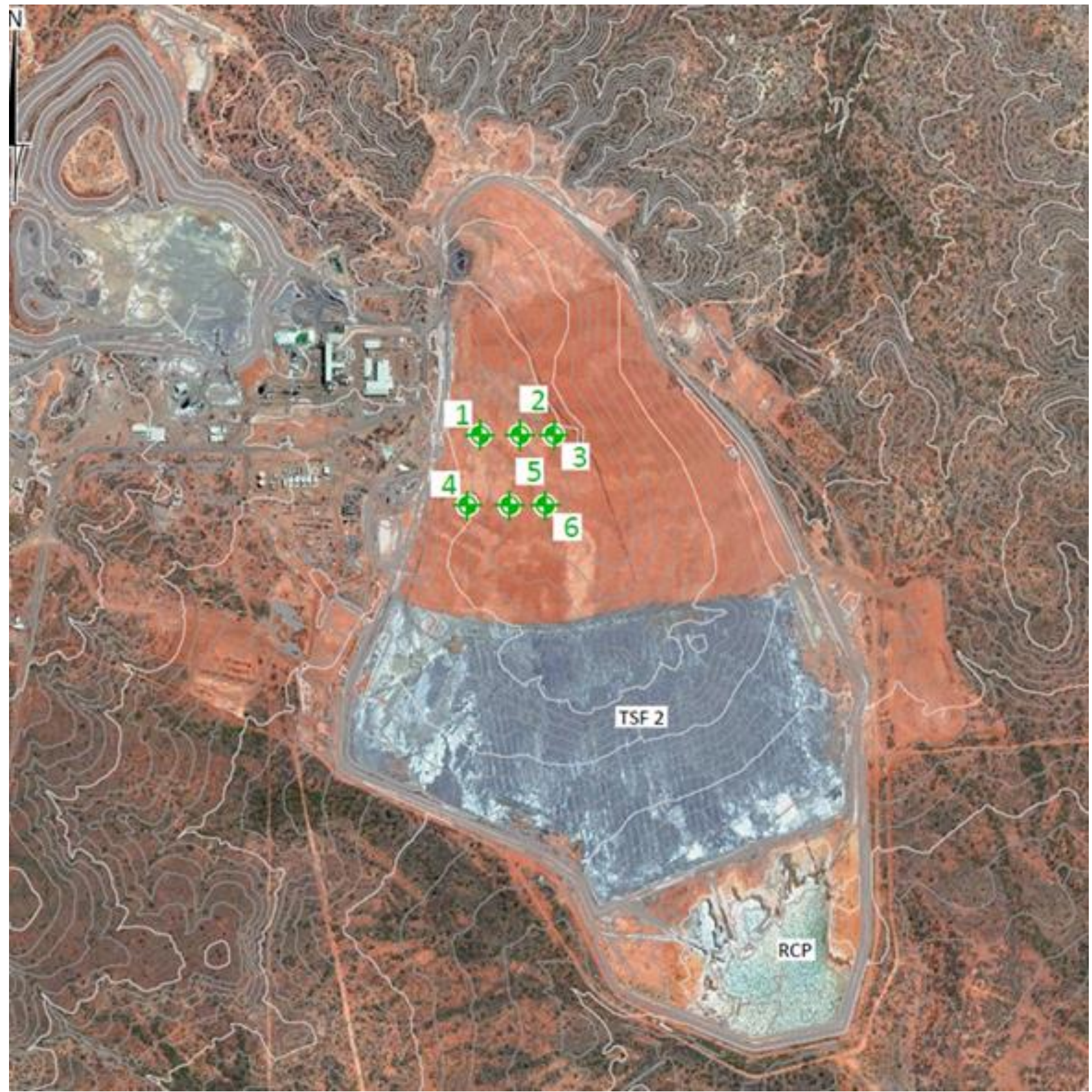

\section{Figure 29 Covered area on TSF2}

To assess the effectiveness of a potential silcrete capillary break layer, trial pits were excavated in 2013 into the dust control cover layer on TSF2 at the locations indicated on Figure 29, and samples were recovered at $10 \mathrm{~cm}$ intervals with depth. Salinity measurements on the recovered samples enabled the determination of the thickness of salt migration through the cover materials. It was found that the salt had been drawn up into the cover to a thickness of $0.2 \mathrm{~m}$. It was concluded that a capillary break layer greater than $0.3 \mathrm{~m}$ should be sufficient to prevent migration of the salts into the topsoil layer.

\subsection{Predicted erosional performance of the cover}

The steeper beach slopes on TSF2 and the shedding nature of the landform suggest that a key cover design issue is that of long-term erosion. A design objective of ensuring that no gulleys in the cover will penetrate the tailings over a period of 500 years was set by Osborne. SIBERIA, a long-term landform modelling program that is able to model gulley formation, has been used in assessing the long-term erosional performance of the trial cover, if this were to be placed on TSF2. Parameters from the rainfall simulation 
trials described in Section 5.6 were applied and it was found that where beach slopes are steeper than 1:30, it is necessary to provide additional thickness to the growth medium layer.

The proposed cover for the steeper slopes has been designed as follows and the typical proposed cross-section is presented in Figure 30:

- $0.2 \mathrm{~m}$ rock mulch layer to promote infiltration to the growth medium layer, overlying.

- Growth medium to a total depth of $0.8 \mathrm{~m}$, based on:

○ $0.5 \mathrm{~m}$ nominal surface cover to account for gulley formation.

○ $0.15 \mathrm{~m}$ to account for long-term cover sheet erosion that could occur.

○ $0.15 \mathrm{~m}$ as a safety factor, overlying.

- $0.5 \mathrm{~m}$ underlying capillary break layer (silcrete) to act as a buffer layer on top of the existing tailings, to reduce any potential uptake of salts from the tailings.

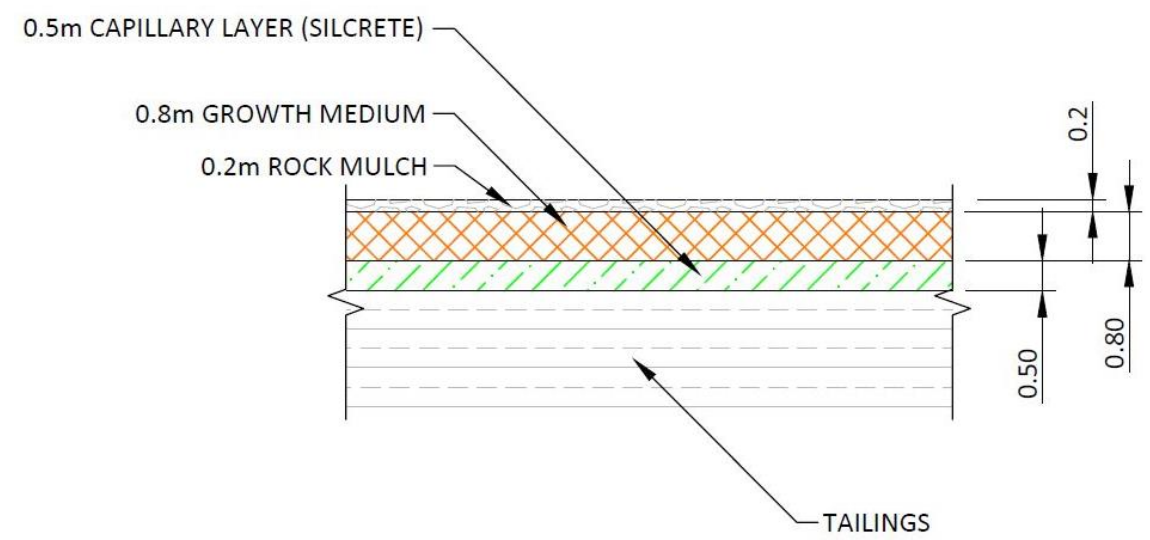

\section{Figure $30 \quad$ TSF2 cover - typical cross-section for steep slopes}

Slopes that are flatter than 1:30 are to receive only a $0.5 \mathrm{~m}$ growth medium layer.

\subsection{Post-closure runoff}

The cover materials to be used on TSF2 will be sourced from natural materials pre-stockpiled at the time of construction of the initial works. The materials are uncontaminated and consequently runoff from the cover should be uncontaminated. Therefore, post-closure, the intention is that once it has been confirmed that runoff from the cover is of an acceptable discharge quality, the runoff will be discharged directly to the environment.

\subsection{Post-closure seepage control}

Seepage arising from the net percolation will naturally emerge in the reclaim pond below TSF2. This seepage will be contaminated and unsuitable for discharge. Post-closure the seepage will be captured using a seepage collection trench and discharged into a lined section of the reclaim pond positioned at the lowest point. All natural runoff will be diverted around this lined area which will serve to evaporate the seepage and any rainfall directly onto the area. Sizing of the area has been carried out using a long-term, climate change adjusted, water balance.

\section{Conclusions}

Implementation of HDTT at Osborne Mine has proved to be both manageable and beneficial in terms of operations, the environment, and sustainability. It took some time to convince management that HDTT would deliver on the benefits, without significantly raising risk levels on the mine, but this allowed for a thorough assessment of beaching, pumping, thickening and geotechnical considerations. The end result is a 
TSF landform that is practical to both cover and close out, and one that blends into the natural environment. Cost benefits in terms of avoidance of embankment raises have been very significant.

\section{Acknowledgement}

The author thanks Osborne Mine for permission to publish this paper.

\section{References}

Charlebois, LE, McPhail, GI, Revington, A \& van Zyl, D 2013, 'Observations of tailings flow and application of the McPhail Beach Profile Model to oil sands and metal mine tailings', in GW Wilson, DC Sego \& NA Beier (eds), Proceedings of Tailings and Mine Waste '13, University of Alberta Geotechnical Center, Edmonton, pp. 169-180.

McPhail, GI 1995, 'Prediction of the beaching characteristics of hydraulically placed tailings', PhD thesis, University of the Witwatersrand.

McPhail, GI, Papageorgiou, G, Noble A \& Wilkinson, D 2004, 'Development and implementation of thickened tailings discharge at Osborne Mine, Queensland, Australia', Proceedings of the 7th International Seminar on Paste and Thickened Tailings, Australian Centre for Geomechanics, Perth.

McPhail, GI 2008, 'Prediction of the beach profile of high density thickened tailings from rheological and small scale trial deposition data', in AB Fourie, RJ Jewell, PT Slatter \& A Paterson (eds), Proceedings of the 11th International Seminar on Paste and Thickened Tailings, Australian Centre for Geomechanics, Perth, pp. 179-188.

McPhail, GI 2014, 'Using small scale flumes to determine rheology at low shear rates', in S Barrera (ed.), Proceedings of the 2nd International Seminar on Tailings management, Gecamin, Santiago.

Papageorgiou, G 2003, 'Flow failure and static liquefaction of gold and platinum tailings', PhD thesis, University of the Witwatersrand.

Willgoose, GR 1989, 'A physically based channel network and catchment evolution model', PhD thesis, Massachusetts Institute of Technology. 
Keynote address 